\title{
Carbon dioxide sequestration in underground formations: review of experimental, modeling, and field studies
}

\author{
Shams Kalam ${ }^{1} \cdot$ Teslim Olayiwola $^{1} \cdot$ Mohammed M. Al-Rubaii $^{1} \cdot$ Benedict I. Amaechi ${ }^{1} \cdot$ Mohammad S. Jamal $^{1}$. \\ Abeeb A. Awotunde ${ }^{1}$
}

Published online: 3 November 2020

(c) The Author(s) 2020

\begin{abstract}
Carbon dioxide has gradually found widespread usage in the field of science and engineering while various efforts have focused on ways to combat the menace resulting from the release of this compound in the atmosphere. A major approach to combating this release is by storage in various geological formations ranging from depleted reservoir types such as saline aquifers to other carbon sinks. In this research study, we reviewed the experimental, modeling, and field studies related to the underground storage of $\mathrm{CO}_{2}$. A considerable amount of research has been conducted in simulating and modeling $\mathrm{CO}_{2}$ sequestration in the subsurface. This review highlights some of the latest contributions. Additionally, the impact of $\mathrm{CO}_{2}$ sequestration on its surroundings due to chemical reactions, adsorption, capillarity, hysteresis, and wettability were reviewed. Some major challenges associated with $\mathrm{CO}_{2}$ injection have also been highlighted. Finally, this work presents a brief history of selected field scale projects such as Sleipner, Weyburn, In Salah, Otway Basin, Snøhvit, Alberta, Boundary Dam, Cranfield, and Ketzin. Thus, this study provides a guide of the $\mathrm{CO}_{2}$ storage process from the perspectives of experimental, modelling, and existing field studies.
\end{abstract}

Keywords $\mathrm{CO}_{2}$ sequestration · Saline aquifers · Capillary trapping $\cdot$ Green house gases $\cdot$ Field scale studies

\section{Introduction}

Carbon dioxide $\left(\mathrm{CO}_{2}\right)$ sequestration refers to the process of capturing the excess $\mathrm{CO}_{2}$ present within the atmosphere toward long-term storage. $\mathrm{CO}_{2}$ storage arises from the need

Abeeb A. Awotunde

awotunde@kfupm.edu.sa

Shams Kalam

shamskalam@hotmail.com; g201306530@kfupm.edu.sa

Teslim Olayiwola

g201806720@kfupm.edu.sa

Mohammed M. Al-Rubaii

g200453260@kfupm.edu.sa

Benedict I. Amaechi

benamaechi@hotmail.com

Mohammad S. Jamal

sarim.jamal@gmail.com

1 Department of Petroleum Engineering, College of Petroleum Engineering \& Geosciences, King Fahd University of Petroleum \& Minerals, Dhahran 31261, Kingdom of Saudi Arabia to mitigate the effects of global warming and serves as an avenue to reduce the rate of accumulation of greenhouse gases (GHG) arising from anthropogenic activities. The presence of these GHGs in the atmosphere can result in environmental pollution (Zhang et al. 2018). Different physical, chemical, and biological processes have been developed to reduce the presence of GHG in the atmosphere. $\mathrm{CO}_{2}$ is one of the major GHG and accounts for $76.7 \%(\mathrm{v} / \mathrm{v})$ of the total GHG concentration (Ramanathan 1988). It is reported that $57-72 \%$ of the GHG effect on global warming is due to $\mathrm{CO}_{2}$ emissions (Lashof and Ahuja 1990). The increasing concentration of $\mathrm{CO}_{2}$ in the atmosphere are being managed using different processes. Examples of these processes include storage of the captured $\mathrm{CO}_{2}$ using depleted reservoir types such as subsurface saline aquifers (Bachu 2000; Emami-Meybodi et al. 2015), ocean water, and other carbon sinks. These geological storage types received widespread acceptance due to their favorable gas distribution, chemistry, permeability, and porosity required for prolonged $\mathrm{CO}_{2}$ storage (Mahmoodpour and Rostami 2017; Riaz and Cinar 2014; Soltanian et al. 2016b, 2018a, b). Sedimentary basins are considered to be promising targets for $\mathrm{CO}_{2}$ storage as 
they have high-porosity and high-permeability layers represented by sandstones, and low-permeable and low-porosity caprocks represented by shale which limit the transfer of $\mathrm{CO}_{2}$ toward the surface. Subsurface sequestration is the easiest route for large-scale sequestration operations. Oil and gas sites have limited capacity; therefore, saline aquifers provide a very attractive alternative for underground sequestration (Lackner 2003). The high salinity of the aquifers is also an important requirement as this highly saline water cannot used for drinking (Marini 2006).

Storage of $\mathrm{CO}_{2}$ in geological formations is called sequestration and it can be achieved in four ways: as a mobile phase within a structural trap, as an aqueous species dissolved in brine, as a precipitated mineral and by capillary entrapment as a residual phase (Bryant et al. 2006).

The first mode requires the presence of an impermeable cap rock which prevents the upward flow of $\mathrm{CO}_{2}$. This is known as hydrodynamic trapping and is only reliable in cases where oil and gas fields and sedimentary basins are well-characterized.

With the passage of time, the injected $\mathrm{CO}_{2}$ dissolves into the formation water and the resulting increase in brine density leads to the sinking of the $\mathrm{CO}_{2}$-laden brine. This process is called solution trapping because the $\mathrm{CO}_{2}$-laden brine does not reach surface. However, this process takes thousands of years under natural conditions (Ennis-King and Paterson 2002).

The third $\mathrm{CO}_{2}$ sequestration process is by mineral trapping, in which case it reacts with the rock to form solid carbonates. This process takes place over thousands to billions of years, depending on how reactive the rock is (Egermann et al. 2005).

The final storage mechanism is capillary trapping in which the sequestered $\mathrm{CO}_{2}$ is trapped at the pore scale by capillary forces. Research has shown that capillary trapping is an efficient storage mechanism. Unlike other mechanisms, all or most of the injected $\mathrm{CO}_{2}$ is trapped and effectively sequestered in a relatively short period of time (within years or decades). The trapped saturations from these experiments are used to calculate the capillary trapping capacities of underground rocks which serve as storage sites for $\mathrm{CO}_{2}$. The capillary trapping capacity of a rock is described as the fraction of the bulk (or total) rock volume which contains the trapped phase. It is given by $\phi S_{-}(n w) r$, where $\phi$ is the porosity of the rock and $S_{-}(n w) r$ is the residual saturation of the non-wetting phase. Thus, the volume of $\mathrm{CO}_{2}$ stored by residual trapping can be obtained by multiplying the bulk volume of the storage formation by the capillary trapping capacity measured from experiment. Figure 1 displays the capillary trapping of $\mathrm{CO}_{2}$ in the pores of the reservoir rock.

Numerous research works have been proposed to understand the ongoing physical and chemical changes occurring within the underground formation. Examples of these

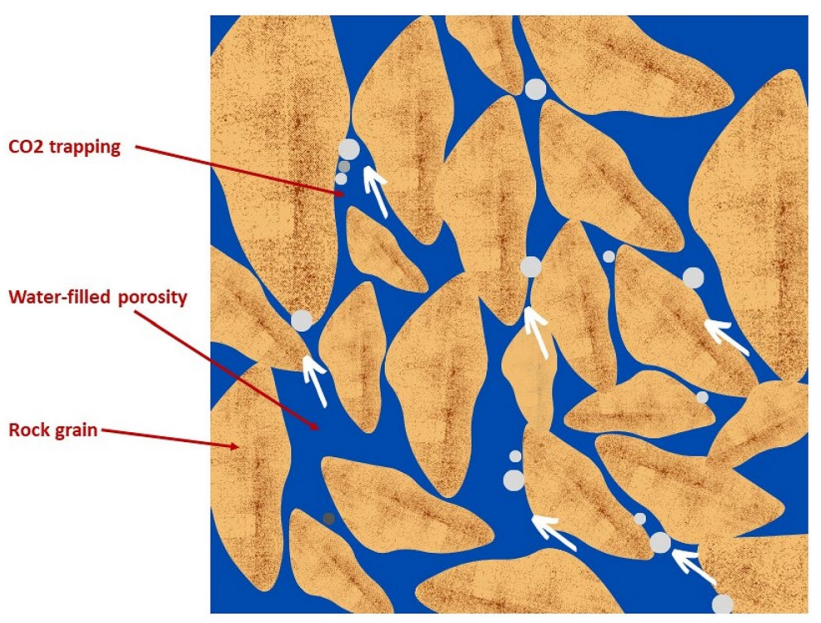

Fig. $1 \mathrm{CO}_{2}$ trapping by capillary trapping mechanism

changes include dissolution, chemical reactions, convective mixing, advective processes, and dispersion. These processes result from the trapping of $\mathrm{CO}_{2}$ below the reservoir traprocks and its resulting decrease in the brine $\mathrm{pH}$.

This article attempts to address a gap in the literature by providing a review of both the experimental and modeling approaches in $\mathrm{CO}_{2}$ underground sequestration. Therefore, the key objective of this research article is to provide insights into the current trends of various experimental and modeling approaches while also documenting past and current practice regarding the storage of $\mathrm{CO}_{2}$. Furthermore, this research output will be useful for researchers and organizations intending to carry out $\mathrm{CO}_{2}$ sequestration operations.

\section{Guidelines for $\mathrm{CO}_{2}$ sequestration operation}

Shafeen et al. (2004) suggested the injection of $\mathrm{CO}_{2}$ into a porous and permeable reservoir covered with a caprock located at least $800 \mathrm{~m}$ beneath the earth's surface where $\mathrm{CO}_{2}$ can be stored under supercritical conditions. They proposed that the injection pressure and temperature should be above the critical pressure and temperature of $\mathrm{CO}_{2}$. They introduced the first study of its kind in Ontario and noted that the methodology would reduce the total $\mathrm{CO}_{2}$ emission. They concluded that establishing adequate safety measures and implementing a contingency plan in case of a blowout of an injection well could be some of the necessary preconditions for sequestration.

The geological formation and lithology play an important part in the success of a $\mathrm{CO}_{2}$ sequestration project. Wellman et al. (2003) studied the interaction between the $\mathrm{CO}_{2}$-brine mixtures with the reservoir rocks. In developing their model, the authors carried a numerical simulation of this interaction using a tool called TRANSTOUGH. Based on their 
findings, the authors observed a strong dependency between the lithology and the amount of $\mathrm{CO}_{2}$ that was injected in the rocks. Factors such as heterogeneity and connectivity of the geological formation result in varying levels of $\mathrm{CO}_{2}$ flow behavior (Soltanian et al. 2016a, b, 2018a, b; Trevisan et al. 2017). Fluvial sedimentary deposits exhibit a characteristically high level of connectivity and discontinuities. Additionally, viscous, capillary, and gravity forces influence the flow of $\mathrm{CO}_{2}$ in all underground formations (Delshad et al. 2013). This interplay between the three forces occur at different phases. For example, in a system undergoing $\mathrm{CO}_{2}$ injection at high injection flow gradient, the viscous effect acts as the driving force on the formation of brine. The effects of gravity and capillarity start after the completion of the injection with a resultant impact on fluid separation and gas trapping.

Friedmann (2007) came up with an idea that serves as the key mode for reducing greenhouse gas emissions. He proposed that to reduce GHGs, the $\mathrm{CO}_{2}$ must be separated from the parent fossil fuels and injected from a large point source into the underground. He stated that the widespread usage of the sequestration process will need a deep understanding of processes involved in the trapping of $\mathrm{CO}_{2}$ underground and also, the need to provide sophisticated methods for monitoring the injection.

Cooper (2009), as part of the $\mathrm{CO}_{2}$ capture project, underlined four distinct phases of $\mathrm{CO}_{2}$ sequestration:

- Site selection and development (3-10 years): During this phase, the site of sequestration is identified.

- Operation (>10 years): The phase when $\mathrm{CO}_{2}$ is injected into the subsurface.

- Closure: The phase during which the injection wells are plugged and the reservoirs are monitored to ensure successful implementation of the sequestration project.

- Post Closure: During this phase, the permanence of the $\mathrm{CO}_{2}$ reservoir is established.

The author also established that three elements are essential for a feasible geological storage: sufficient pore volume to store the gas, sealing layer to ensure containment, and high injectivity is necessary (high permeability, > $100 \mathrm{mD}$ ).

Cherepovitsyn and Ilinova (2016) outlined the main approaches to the implementation of $\mathrm{CO}_{2}$ sequestration technologies in the oil and gas industry in Russia, and also identified the ecological, economic, and social issues of their usage. They indicated that promotion of the technology of $\mathrm{CO}_{2}$ sequestration by means of capturing and injecting it into underground reservoirs is a promising mechanism of reducing the $\mathrm{CO}_{2}$ concentration. In addition, they mentioned that $\mathrm{CO}_{2}$ capture and storage (CCS) technologies might be used to enhance oil recovery $\left(\mathrm{EOR}-\mathrm{CO}_{2}\right)$ and production by oil extraction and decreasing oil viscosity. They presented some conceptual view of the potentially sustainable implementation of EOR- $\mathrm{CO}_{2}$ technologies within the context of the oil and gas industry.

\section{Determination of the $\mathrm{CO}_{2}$ storage capacity}

Understanding the storage capacity of any proposed $\mathrm{CO}_{2}$ storage medium is a key stage during consideration. Recent methods used in previous applications have focused on the use of the effective pore volume available in the mass balance approach and limited to open formations. Most storage systems are composed of compartmentalized reservoir systems with characteristically low permeability regions. Not all systems are open; recent studies by Muggeridge et al. (2004) and Puckette et al. (2003) reported the existence of reservoirs with no communication with the adjoining formations, i.e., closed system. Zhou et al. (2008) proposed a numerical method to estimate the storage capacity of both closed and semi-closed systems. In developing their model, the authors used the TOUGH2/ECO2N simulator and proposed a model based on the assumption that the amount of injected $\mathrm{CO}_{2}$ will result in a pressure build-up and that the $\mathrm{CO}_{2}$ displaces an equivalent amount of reservoir formation fluid. The proposed model is based on Eq. (1), as follows:

$V_{\mathrm{co}_{2}}\left(t_{\mathrm{I}}\right)=\left(\beta_{\mathrm{p}}+\beta_{\mathrm{w}}\right) \times V_{\mathrm{f}} \times \Delta p\left(t_{\mathrm{I}}\right)$

where $V_{\mathrm{co}_{2}}\left(t_{\mathrm{I}}\right)$ is the pore volume (PV) of the injected $\mathrm{CO}_{2}$ at injection time $\left(t_{\mathrm{I}}\right), \Delta p\left(t_{\mathrm{I}}\right)$ is the average pressure build up at $t_{\mathrm{I}}, \beta_{\mathrm{p}}$ and $\beta_{\mathrm{w}}$ represent the pore and brine compressibility and $V_{\mathrm{f}}$ is the initial PV of the formation.

Additionally, Zhang et al. (2011) proposed another method to estimate the $\mathrm{CO}_{2}$ storage capacity of oil reservoirs. They assumed the existence of a non-interacting reservoir system and that the $\mathrm{CO}_{2}$ storage can be calculated independently for the different trapping mechanisms. Zhang et al. proposed a model that encompasses the amount of $\mathrm{CO}_{2}$ in the oil zone $\left(V_{\text {co2-in-oil }}\right)$ and water zone $\left(V_{\text {co2-in-aquifer }}\right)$ as shown in Eq. (2):

$V_{\mathrm{co}_{2}}=V_{\mathrm{co}_{2}-\text { in - oil }}+V_{\mathrm{co}_{2} \text { - in - aquifer }}$

$$
\begin{aligned}
V_{\mathrm{co}_{2} \text { - in - oil }}= & \rho_{\mathrm{cor}} \times\left[\frac{\left(R_{\mathrm{f}}+R_{\mathrm{EOR}}\right) \times \mathrm{OOIP} \times B_{\mathrm{o}}}{\rho_{\mathrm{os}}+\left(V_{\mathrm{pw}}-V_{\mathrm{iw}}\right) \times B_{\mathrm{w}}}\right] \\
& +\left(\mathrm{OWIP}+V_{\mathrm{iw}}-V_{\mathrm{pw}}\right) \times R_{\mathrm{w}}^{\mathrm{co} 2} \\
& +\left(1-R_{\mathrm{f}}-R_{\mathrm{EOR}}\right) \times \frac{\mathrm{OOIP}}{\rho_{\mathrm{os}} \times R_{\mathrm{o}}^{\mathrm{co} 2}}
\end{aligned}
$$

$$
\begin{aligned}
V_{\mathrm{co}_{2}-\text { in - aquifer }}= & A \times D \times \phi\left\{a \times S_{g}^{\text {struc }} \times \rho_{\mathrm{coa}}+b \times\left(1-S_{g}^{\mathrm{struc}}\right) \times \rho_{\mathrm{coa}}\right. \\
& \left.+\left[a \times\left(1-S_{g}^{\text {struc }}\right)+b \times\left(1-S_{g}^{\text {resid }}\right)+(1-a-b)\right] \times R_{w}^{\mathrm{co} 2}\right\}
\end{aligned}
$$


where $\rho_{\text {cor }}$ is the density of $\mathrm{CO}_{2}$ at the reservoir condition; $\rho_{\text {coa }}$ is the density of $\mathrm{CO}_{2}$ in the water zone; $\rho_{\mathrm{os}}$ is the surface density of the oil, OOIP is the oil initially in place; $B_{\mathrm{o}}$ is the oil formation volume factor; $B_{\mathrm{w}}$ is the water formation volume factor; $V_{\mathrm{pw}}$ is the total amount of produced water at the surface, $V_{\mathrm{iw}}$ is the amount of injected or invaded water at the surface; $R_{\mathrm{o}}^{\mathrm{co} 2}$ and $R_{\mathrm{w}}^{\mathrm{co} 2}$ represents the solubility of $\mathrm{CO}_{2}$ in residual oil and water, respectively; $R_{\mathrm{f}}$ and $R_{\mathrm{EOR}}$ are the recovery factor of water flooding and $\mathrm{CO}_{2}$ injection, respectively; $\phi, A$, and $D$ represent the porosity, area, and thickness of the associated water zone, respectively; $S_{g}^{\text {struc }}$ and $S_{g}^{\text {resid }}$ are the saturation of $\mathrm{CO}_{2}$ in the trapping structure and residual $\mathrm{CO}_{2}$ in the associated aquifer, respectively; and $a$ and $b$ are the volume fractions of the structure and residual gas trapping zone of the associated water zone, respectively.

Okwen et al. (2010) proposed a conceptual model to estimate the storage efficiency of saline aquifers. The authors assumed the presence of an inert porous medium, constant temperature, constant fluid density and viscosities over time and space, existence of high temperature $\mathrm{CO}_{2}$, immiscible fluid $\left(\mathrm{CO}_{2}+\right.$ brine $)$ phase, infinitely large radial aquifer system with small thickness, predominantly horizontal flow, and constant injection rate of $\mathrm{CO}_{2}$. They proposed two numerical models given by the equation below that relates the storage efficiency of a saline aquifer $(\in)$ to the residual saturation, $\mathrm{CO}_{2}$-Brine mobility ratio, and dimensionless constant.

$\Gamma=\frac{2 \pi \Delta \rho k \lambda_{\mathrm{b}} B^{2}}{Q_{\text {well }}}$

If $0 \leq \Gamma \leq 0.5$,

$\in \approx\left(1-S_{r}\right) \frac{1}{\lambda}$

If $0.5 \leq \Gamma \leq 50$,

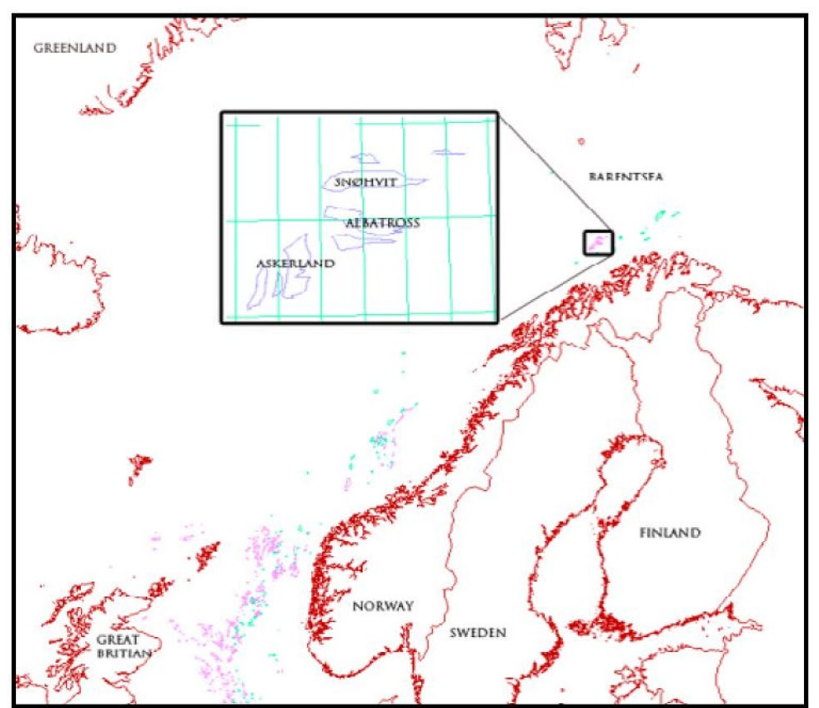

Fig. 2 Field location (Pham et al. 2011)

a model that assumes the storage capacity of the geologic formation is given by the mass of $\mathrm{CO}_{2}$ that would result in leakage. Equation (8) gives the model by Kopp et al. (2009) that relates the effective mass of stored $\mathrm{CO}_{2}\left(M_{\text {eff }}\right)$ to the average porosity $(\phi)$, density of $\mathrm{CO}_{2}\left(\rho_{\mathrm{co} 2}\right)$ at particular temperature $(T)$ and pressure $(p)$, and the total reservoir volume $\left(V_{\text {tot }}\right)$.

$M_{\text {eff }}=\phi \times C_{\mathrm{h}} \times\left(C_{\mathrm{ig}} C_{\mathrm{gg}}+C_{\mathrm{il}} C_{\mathrm{gl}}\right) \times V_{\mathrm{tot}} \times \rho_{\mathrm{co} 2}(T, p)$

where $C_{\mathrm{h}}, C_{\mathrm{ig}}, C_{\mathrm{gg}}, C_{\mathrm{il}}$, and $C_{\mathrm{gl}}$ represents the heterogeneous capacity coefficient, intrinsic capacity occupied by the gas phase, intrinsic capacity coefficient occupied by the liquid phase, geometric capacity for the liquid, and geometric capacity of gas phase, respectively.

In other related studies, Pham et al. (2011) developed a numerical model to estimate the amount of $\mathrm{CO}_{2}$ that was

$\in \approx \frac{2\left(1-S_{r}\right)}{(0.0324 \lambda-0.0952) \Gamma+(0.1778 \lambda+5.9682) \Gamma^{0.5}+1.6962 \lambda-3.0472}$

where $\Gamma$ is the dimensionless number, $\lambda$ is the ratio of the mobility of $\mathrm{CO}_{2}$ to brine, $\Delta \rho$ is the difference between the brine and $\mathrm{CO}_{2}$ density, $g$ is the gravitational acceleration, $\lambda_{\mathrm{b}}$ is the mobility of brine, and $k$ is the absolute permeability of the geologic formation.

It is worth mentioning that there exist several methods to estimate the storage capacity of the different geological storage systems. Additionally, the accuracy of these models depends upon the type of storage system, level of certainty in the data and, availability of information required to accurately estimate the storage capacity of the formation (Kopp et al. 2009). To account for the uncertain nature of reservoir systems, Kopp et al. (2009) proposed proposed to be injected into the Tubåen formation from the Snohvit field, Barents Sea (Fig. 2).

The injected $\mathrm{CO}_{2}$ increases the reservoir pressure and it is, therefore, necessary to monitor the increase in pressure such that it does not exceed the fracture pressure which in turn would lead to formation failure. The authors evaluated whether porosity can be considered as a factor in selecting a candidate reservoir/aquifer for $\mathrm{CO}_{2}$ sequestration. The logging tools proposed that the porosity of the formation might be a good indicator in deciding a candidate for $\mathrm{CO}_{2}$ injection. Klara et al. (2003) conducted an integrated collaborative technology program for $\mathrm{CO}_{2}$ sequestration in a geologic formation. The main objective 
was to predict the stored volume of $\mathrm{CO}_{2}$ left in the formation since the remaining amount contributed toward global warming. They studied and proposed a flowchart for better accentuation.

Economides and Economides (2010) proposed a model based on material balance to report on the failure of sequestration in addressing the necessity of storing $\mathrm{CO}_{2}$ in a closed system. Their calculations suggest that the volume of the liquid or supercritical $\mathrm{CO}_{2}$ to be disposed cannot exceed $1 \%$ of the pore volume. Thus, this will require 5 to 20 times more underground reservoir volume than has been envisioned by other studies, rendering geologic sequestration of $\mathrm{CO}_{2}$ a profoundly non-feasible option for the management of $\mathrm{CO}_{2}$ emissions. The results of the material balance modeling showed that the quantity of $\mathrm{CO}_{2}$ injected in the liquid stage (larger mass) obeys an analogue of the single phase, liquid material balance, long-established in the petroleum industry for forecasting undersaturated oil recovery. They indicated that the total volume that can be stored is a function of the initial reservoir pressure, the fracturing pressure of the formation of an adjoining layer, and the $\mathrm{CO}_{2}$ and water compressibility and mobility values.

\section{Experimental approach}

This section of the review analyzes the experimental studies of $\mathrm{CO}_{2}$ sequestration in different underground formations such as; saline aquifers (Cinar et al. 2007; Izgec et al. 2005; Jeddizahed and Rostami 2016; Liu and Maroto-Valer 2011; Mohamed and Nasr-El-Din 2013; Oloruntobi and LaForce 2009; Taheri et al. 2012), shales (Jin et al. 2017), deep coal seams (Prusty 2008; Wang et al. 2016), and depleted gas reservoirs (Luc et al. 2004). The studies are also aimed at determining the amount of injected $\mathrm{CO}_{2}$ that can be stored as an immobile phase at the pore scale.

Jin et al. (2017) conducted an experimental study on Bakken shales to analyze $\mathrm{CO}_{2}$ EOR and its storage in unconventional oil formations. $\mathrm{CO}_{2}$ adsorption isotherm indicated that substantial amount of $\mathrm{CO}_{2}$ can be trapped $(\sim 17 \mathrm{mg} / \mathrm{g})$ in the Bakken shale for a broad pressure range (0-40 MPa).

Prusty (2008) performed an experimental study on coal samples from three coal seams to investigate the potential of sequestration and enhanced gas recovery (EGR). The results of this research advised that the sorption behavior could not be generalized for different types of coals. This was because of different sorption behavior showed by those studied coal samples. Wang et al., (2016) studied the interaction of $\mathrm{CO}_{2}$ with rock and brine in deep coal seams. The interaction of calcareous mudstone with $\mathrm{CO}_{2}$ /brine results in the changes of mineralogy which improves the $\mathrm{CO}_{2}$ sequestration capacity of deep coal seams.
Luc et al. (2004) performed several experimental studies on understanding the sequestration of supercritical $\mathrm{CO}_{2}$ in carbonate core samples obtained from depleted gas reservoirs. The core porosity and fluid saturation were evaluated using an X-ray CT scanner. The study revealed that longitudinal dispersion coefficient of $\mathrm{CO}_{2}$ under isothermal conditions reduces with rising pressure and increases with temperature under isobaric conditions.

A vast amount of literature is available for $\mathrm{CO}_{2}$ sequestration in saline aquifers. Jeddizahed and Rostami (2016) conducted an experimental study on the precipitation of salt due to the interaction between $\mathrm{CO}_{2}$ and the aquifer surface during sequestration. It was concluded that the amount of salt precipitation increases with salinity and reduces with the injection rate. A comprehensive review was conducted to show the parameters influencing mineral trapping of $\mathrm{CO}_{2}$ sequestration in brines which includes, pressure, temperature, $\mathrm{pH}$ of brine and composition of brine (Liu and MarotoValer 2011). Brine $\mathrm{pH}$ was found to be the most dominant parameter as a high value of $\mathrm{pH}(>9)$ supports precipitation of carbonate minerals. Cinar et al. (2007) investigated the effects of viscous, gravitational, and capillary factors in the $\mathrm{CO}_{2}$ injection. Experiments were conducted in glass containing bead packs which helped in determining the regimes of pore scale instability. Izgec et al. (2005) performed an experimental study using computerized tomography (CT) for the capacity of sequestration in a carbonate aquifer. Alteration in permeability for varying injection rates of $\mathrm{CO}_{2}$, pressure, and temperature at various salt concentrations were presented. $\mathrm{CO}_{2}$ sequestration by mineral trapping was found to be smaller than solubility trapping in that study. Oloruntobi and LaForce (2009) analyzed the impact of aquifer heterogeneity on $\mathrm{CO}_{2}$ sequestration using experimental studies, which shows that trapping is greatly influenced by heterogeneity. The results show that poorly consolidated sands trapped less air than well consolidated sands. Sequestration of $\mathrm{CO}_{2}$ into brines leads to a higher mixture density. The impact of convection due to density on the dissolution rate was investigated experimentally (Taheri et al. 2012). Authors also compared the results with simulation studies. Interaction of $\mathrm{CO}_{2}$ with rock and brine during $\mathrm{CO}_{2}$ injection into carbonates results in precipitation which dampens the well injectivity. Experimental studies were conducted to investigate the permeability loss using core floods (Mohamed and Nasr-El-Din 2013). Large amount of damage was seen in more heterogenous cores. Precipitates reduces the permeability of cores with high permeability, while $\mathrm{CO}_{2}$-brine capillary forces enhance the permeability reduction for the low permeability cores. Table 1 lists the key finding of experimental studies on Carbon dioxide sequestration. 


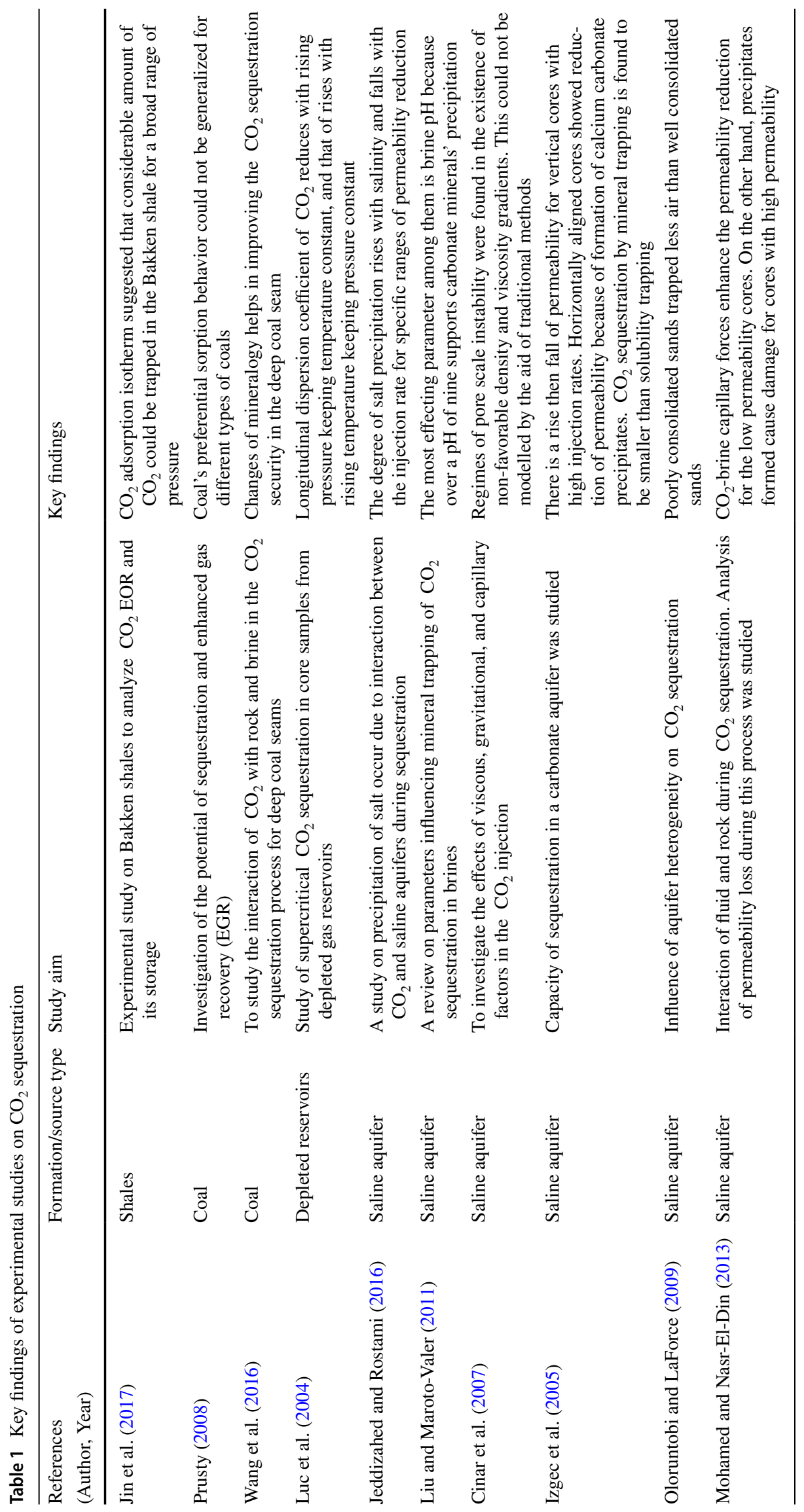




\section{Numerical modeling and simulation of $\mathrm{CO}_{2}$ sequestration}

A considerable amount of research has been conducted in simulating and modeling $\mathrm{CO}_{2}$ sequestration in the subsurface. Calabrese et al. (2005) studied the physical and chemical processes during $\mathrm{CO}_{2}$ sequestration in a depleted gas reservoir located in the north of Italy. They concluded that to maximize the volume of $\mathrm{CO}_{2}$ injected, an optimum rate has to be defined. At higher rates, the gas channels through high permeability streaks, and hence the storage capacity is reduced. While at lower rates, the denser $\mathrm{CO}_{2}$ falls to the bottom of the gas zone and dissolves in the aquifer. They also concluded that molecular diffusion, dispersion, and geochemistry were not important factors for assessing the $\mathrm{CO}_{2}$ storage.

Seo and Mamora (2005) performed experimental and simulation studies to evaluate the feasibility of sequestering supercritical $\mathrm{CO}_{2}$ in depleted gas reservoirs. They performed experimental studies to obtain relative permeability curves; then, 3D simulation models of one-eighth of a five-spot pattern were used to evaluate the injection of $\mathrm{CO}_{2}$.

Hesse (2008) presented a compact multiscale finite volume (CMSFV) method for the numerical simulation of $\mathrm{CO}_{2}$ storage in large-scale heterogeneous formations. The authors identified that dissolution is an important trapping process if $\mathrm{CO}_{2}$ is present in a structural trap. They also concluded that high permeability aquifers favor dissolution trapping. The authors indicated that high permeability, gently dipping, and deep saline aquifers are the optimal targets for $\mathrm{CO}_{2}$ sequestration.

Momeni et al. (2012) presented a simulation study using ECLIPSE E300 (compositional simulation model) of a synthetic geologic model used to sequestrate $\mathrm{CO}_{2}$. They concluded that the operating expenditure for sequestration in a depleted oil reservoir is less than in an aquifer because of lower well corrosion during injection. This is due to the higher brine concentration in an aquifer which increases the probability of corrosion.

There is a lack of understanding of the detailed mechanism of subsurface sequestration. This is due to the lack of information regarding the heterogeneity and the geometry of the reservoir/aquifer selected for sequestration. The success of sequestration depends on the injection rate, injection pressure, injection strategy, and the type and orientation of the injection well. Zhang and Agarwal (2012) performed an optimization based on genetic algorithms to optimize the sequestration operation. They used the TOUGH2 solver developed by the US Department of Energy. They used both horizontal and vertical wells. Based on the results of the optimization, they concluded that the horizontal wells were much better when compared to vertical wells in aspects such as reduced migration and pressure build-up which could contribute to cap rock fracture and gas leakage.

Bao et al. (2016) performed a large-scale $\mathrm{CO}_{2}$ sequestration by coupling reservoir simulation with molecular dynamics (MD). The simulation was performed on massively parallel high-performance computing systems. They believed the coupling of molecular dynamics would provide better predictability of fluid properties under varying geological conditions. In their flow equations, they assumed the flow to be incompressible and used Darcy's equation to model the velocity in the reservoir. The advection diffusion equation was used to model the transport of $\mathrm{CO}_{2}$ in the porous media. In the MD simulation, they solved Newton's equation of motion and the Leonard Jones and Coulomb interactions were used to represent the interaction between two atoms.

Hao et al. (2016) developed a methodology to combine reservoir simulation, rock physics theory, and seismic modeling to simulate and monitor a sequestration process in an idealized geological model located in the Sleipner field. They modelled $\mathrm{CO}_{2}$ injection using the two-phase flow model and solved the equations using the IMPES method. Then, they analyzed the effects of fluid saturation and pressure change on the elastic wave velocity based on the Gassman equation, Hertz-Mindlin theory, and effective fluid theory. Finally, seismic modeling was performed using P-wave potential equations and the symplectic stereomodeling (SSM) method on the transformed geologic model obtained from reservoir simulation.

Foroozesh et al. (2018) performed a field scale simulation of an aquifer consisting of one well injecting $\mathrm{CO}_{2}$ for ten years. The model was run for 100 years with the results showing that $\mathrm{CO}_{2}$ solubility trapping was the main mechanism of sequestration. The simulation was performed using CMG-GEM. The results demonstrated that good vertical permeability and lower injection pressures are important factors in reducing leakage.

Mkemai and Bin (2019) investigated the optimal injection strategy to enhance $\mathrm{CO}_{2}$ storage. Their results concluded that an optimum injection pressure needs to be maintained as the pressure build-up created by injection may fracture the cap rock, which would then lead to $\mathrm{CO}_{2}$ leakage. The authors highlighted that an optimum $\mathrm{CO}_{2}$ sequestration does not lead to excessive migration of the injected gas. Table 2 summarizes a few of the latest additions in modeling and simulation studies on $\mathrm{CO}_{2}$ sequestration.

\section{Effects of $\mathrm{CO}_{2}$ sequestration}

This section outlines the direct impacts of $\mathrm{CO}_{2}$ sequestration on its surroundings. 


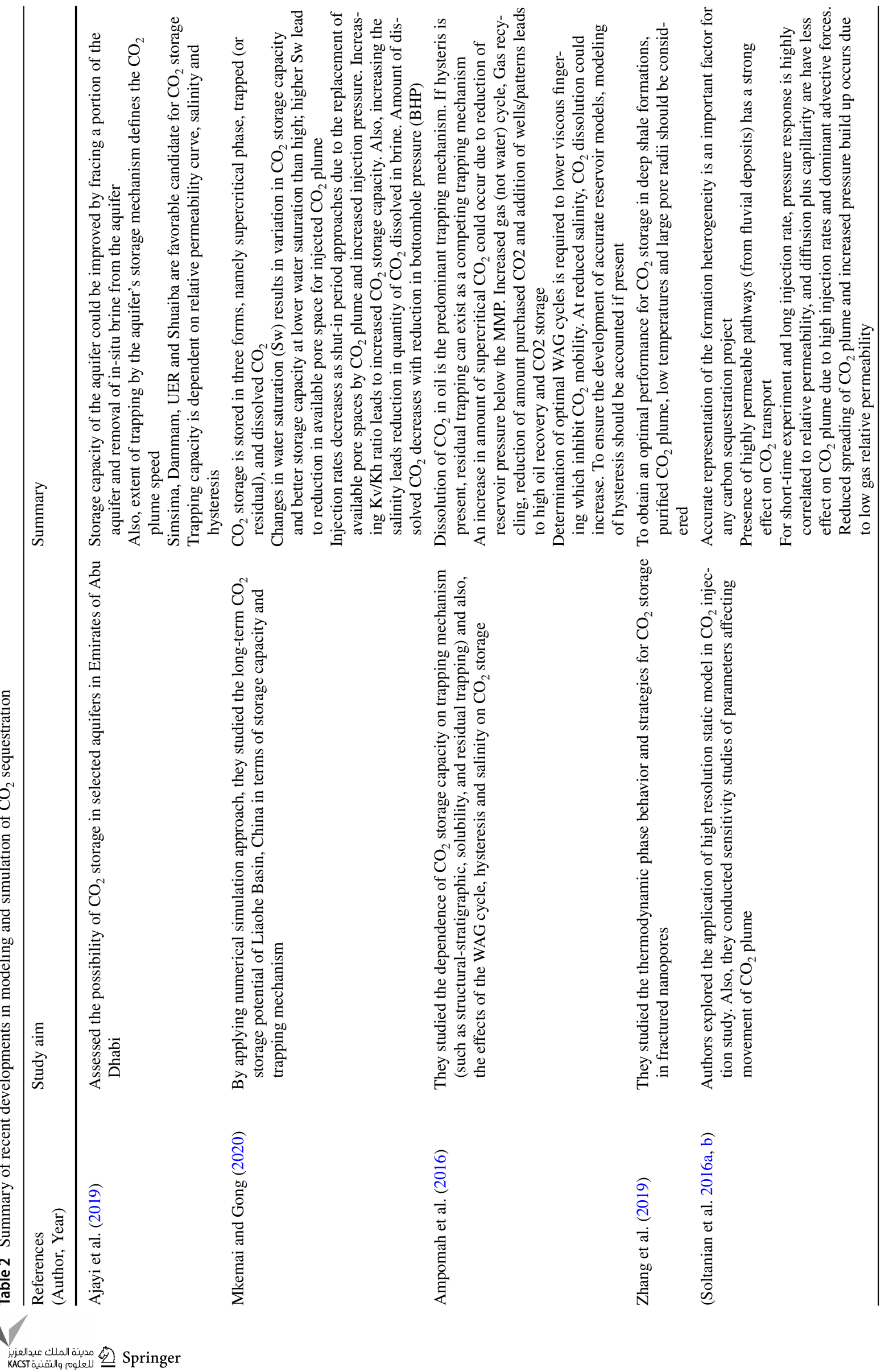




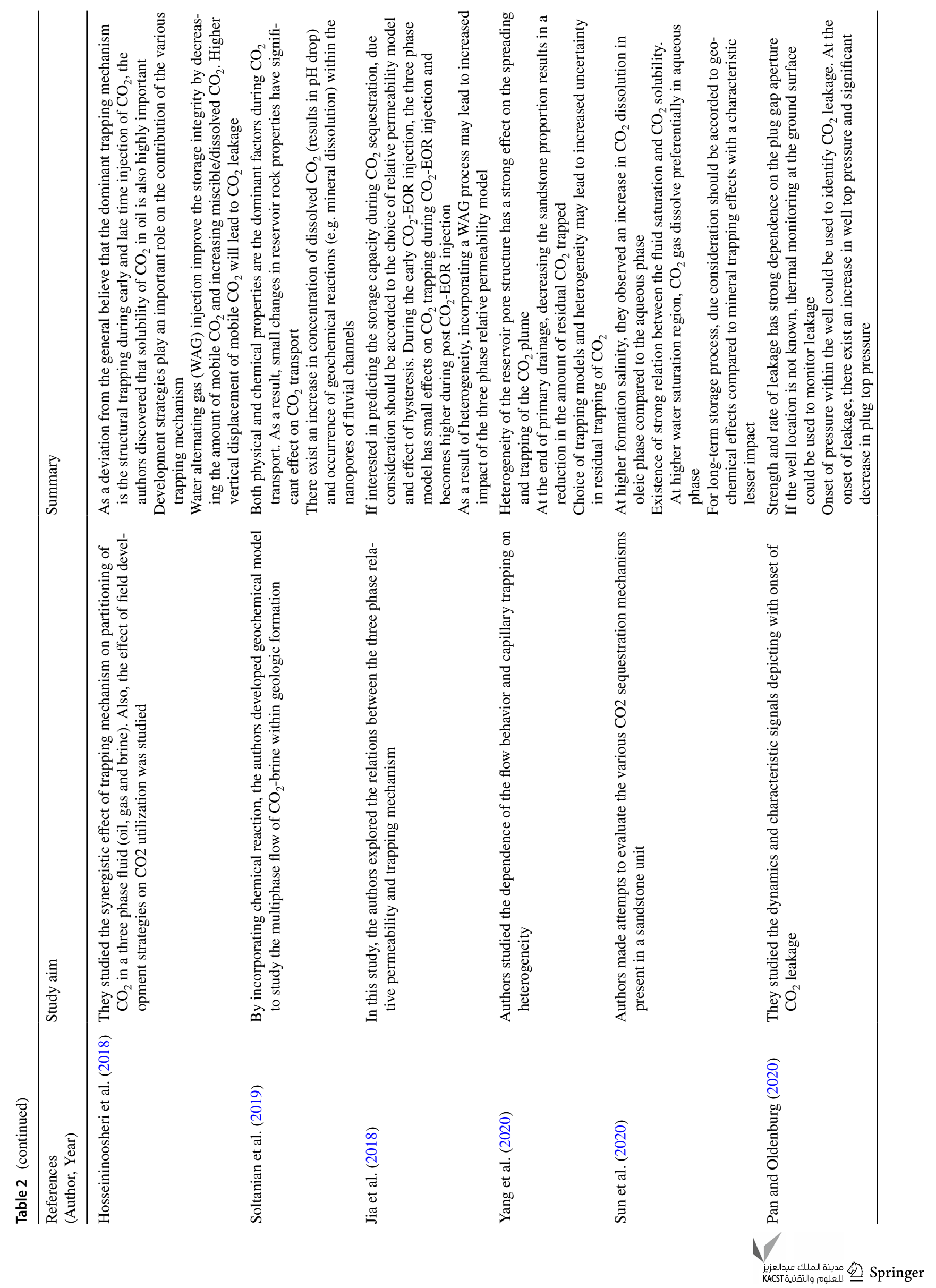




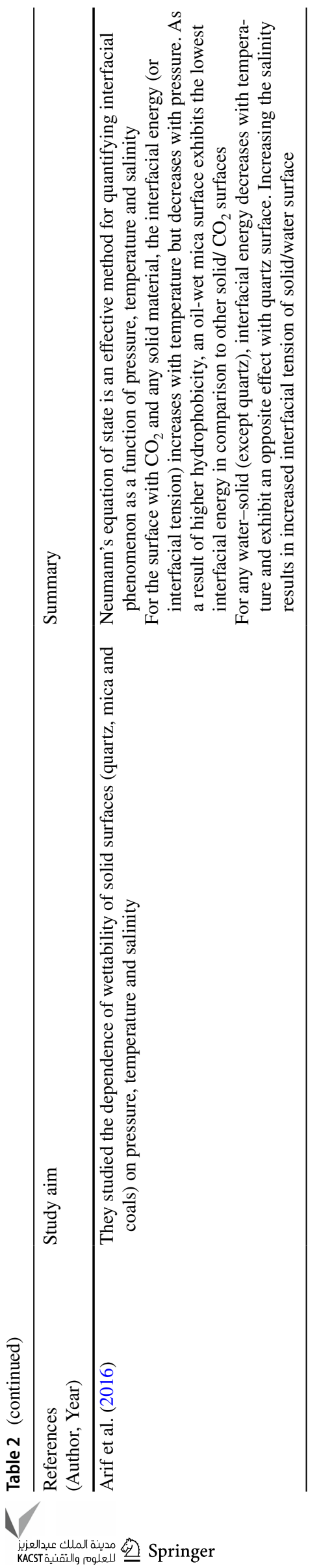

\section{Effect due to chemical reactions}

Soltanian et al. (2019) performed a field scale simulation of the injection of $\mathrm{CO}_{2}$ in an aquifer saturated with brine using a compositional model. Additionally, the authors investigated the effects of geochemical reactions on the pressure response and breakthrough times of the reservoir. The authors observed the time-dependent behavior of the $\mathrm{pH}$ and mineral changes of the aquifer located in a fluvial environment. The bottom-hole flowing pressure profile did not exhibit significant differences when compared with the observations from reactive transport simulations by Hosseini et al. (2013). For a system with weak reactivity, the effects of including capillary and compositional reactions were negligible and the difference between the BHP for both these cases was insignificant. Small variations in petrophysical properties can significantly affect the migration of $\mathrm{CO}_{2}$ with regards to the breakthrough times.

\section{Effect of adsorption}

Viete and Ranjith (2006) performed a study to explore the effects of the adsorption of $\mathrm{CO}_{2}$ on the compressive strength and permeability of Southeast Australian brown coal. The results of the study showed a noticeable compressive strength decrease. However, further testing is required to reveal the reason for the apparent negligible strength reduction with $\mathrm{CO}_{2}$ adsorption at higher confinement. The authors conducted $\mathrm{CO}_{2}$ outflow measurements during the stress-strain process, and demonstrated an initial permeability decrease with pore closure, followed by a significant increase in permeability with fracturing. They indicated that when dealing with coal seam $\mathrm{CO}_{2}$ sequestration, it is important to consider the effect of the localized in-situ stresses and whether they are sufficient to initiate fracturing due to adsorptive weakening. Lastly, they mentioned that coal properties (e.g., rank, moisture content) are likely to affect the geo-mechanical influence of $\mathrm{CO}_{2}$ adsorption, and discussed the expected magnitude of the proposed fracture related to permeability increase.

\section{Effects of capillarity, hysteresis, and wettability}

In microscopic pore spaces, capillary pressure has a strong effect on flow (Delshad et al. 2013). During $\mathrm{CO}_{2}$ storage, the capillary effect becomes important due to the hysteresis effect. In a previous study by Hebach et al. (2002), the interfacial tension between the brine and supercritical $\mathrm{CO}_{2}$ has been observed to have a direct relationship with temperature and salinity and an inverse relationship with pressure. Delshad et al. (2013) proposed a numerical method to study the impact of trapping and hysteresis on $\mathrm{CO}_{2}$ storage using the Cranfield field data. In systems with trapping but no 
capillary hysteresis, the author observed an upward movement of the $\mathrm{CO}_{2}$ relative permeability curve and a reduced residual $\mathrm{CO}_{2}$ saturation and bottom-hole pressure of the injection well. Additionally, a reduced $\mathrm{CO}_{2}$ migration exists when the residual gas saturation increases, demonstrating the effect of hysteresis on $\mathrm{CO}_{2}$.

Iglauer et al. (2015) reviewed published studies on the effects of $\mathrm{CO}_{2}$ wettability in storage and seal rocks. They introduced the wettability concept and explained its importance in geo-sequestration (CGS) projects. In addition, they showed a dramatic impact caused by wettability during structural and residual trapping of $\mathrm{CO}_{2}$. They concluded with a few discoveries about sandstone and limestone, in addition to pure minerals; for example, quartz, calcite, feldspar, and mica are unequivocally water wet in a $\mathrm{CO}_{2}$-water system, while oil-wet limestone and oil-wet quartz or coal exhibit intermediate wettability in a $\mathrm{CO}_{2}$-water framework. Based on their findings, the authors opined that the contact angle alone is insufficient to predict capillary pressures in either reservoir or seal rocks. Their findings are shown in Figs. 3, 4 , and 5.

Kim et al. (2013) developed a model to measure the thicknesses of $\mathrm{KCSI}_{2}$ brine films on two different roughness mica surfaces under conditions representative of geological $\mathrm{CO}_{2}$ sequestration $\left(7.8 \mathrm{MPa}\right.$ and $40{ }^{\circ} \mathrm{C}$ ) to understand the influences of mineral surface roughness and capillary potential. The measured brine thicknesses on the Mica 1 (smooth) and Mica 2 (rough) surfaces were 23-8 $\mathrm{nm}$ and $491-412 \mathrm{~nm}$, respectively.
- Iglauer et al 2012 (350K, water)

4 McCaughan et al 2012 (4.5 OH groups per nm2, 300K, water)

- McCaughan et al 2012 (1.7 OH groups per nm2, 300K, water)

" McCaughan 2012 (300K, $1 \mathrm{M} \mathrm{NaCl}$ brine)

- McCaughan 2012 (300K, $1 \mathrm{M} \mathrm{MgCl} 2$ brine)

-McCaughan 2012 (300K, $1 \mathrm{M} \mathrm{CaCl} 2$ brine)

Liu et al. 2010* (318.15K, water)
-Iglauer et al 2012 (300K, water)

- McCaughan et al 2012 (3.7 OH groups per nm2, 300K, water)

- McCaughan 2012 (300K, water)

- McCaughan 2012 (300K, $4 \mathrm{M} \mathrm{NaCl}$ brine)

- McCaughan 2012 (300K, 4M MgCl2 brine)

A McCaughan 2012 (300K, 4M CaCl2 brine)

Liu et al, 2010** (1.6 OH groups per nm2, 318.15K, water)

-Tsuji et al. 2013 (9.5 oH groups per nm2, 296K)

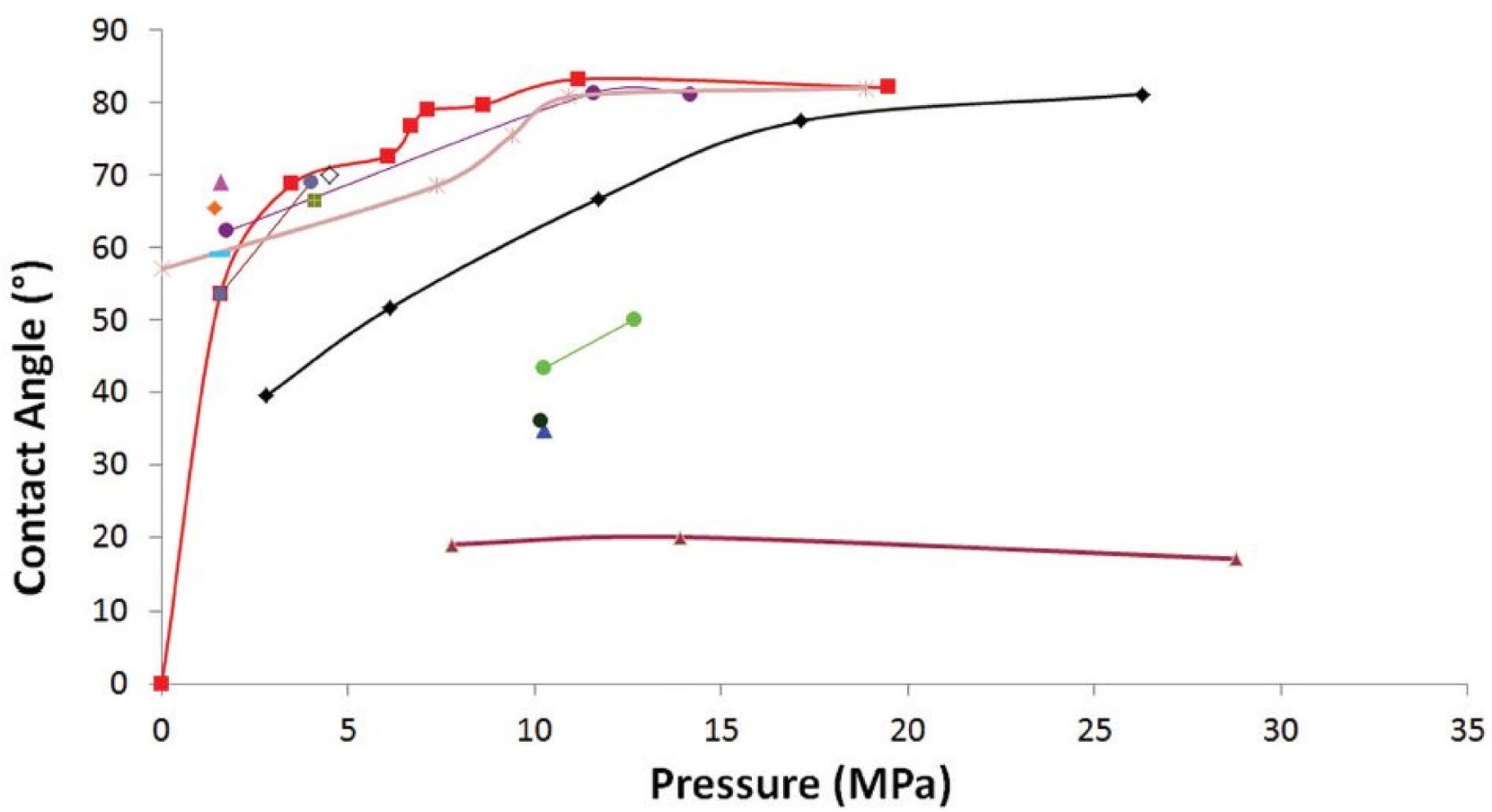

Fig. 3 Molecular dynamics simulation for the determination of water contact angles on quartz and b-cristobalite surfaces (Iglauer et al. 2015) 

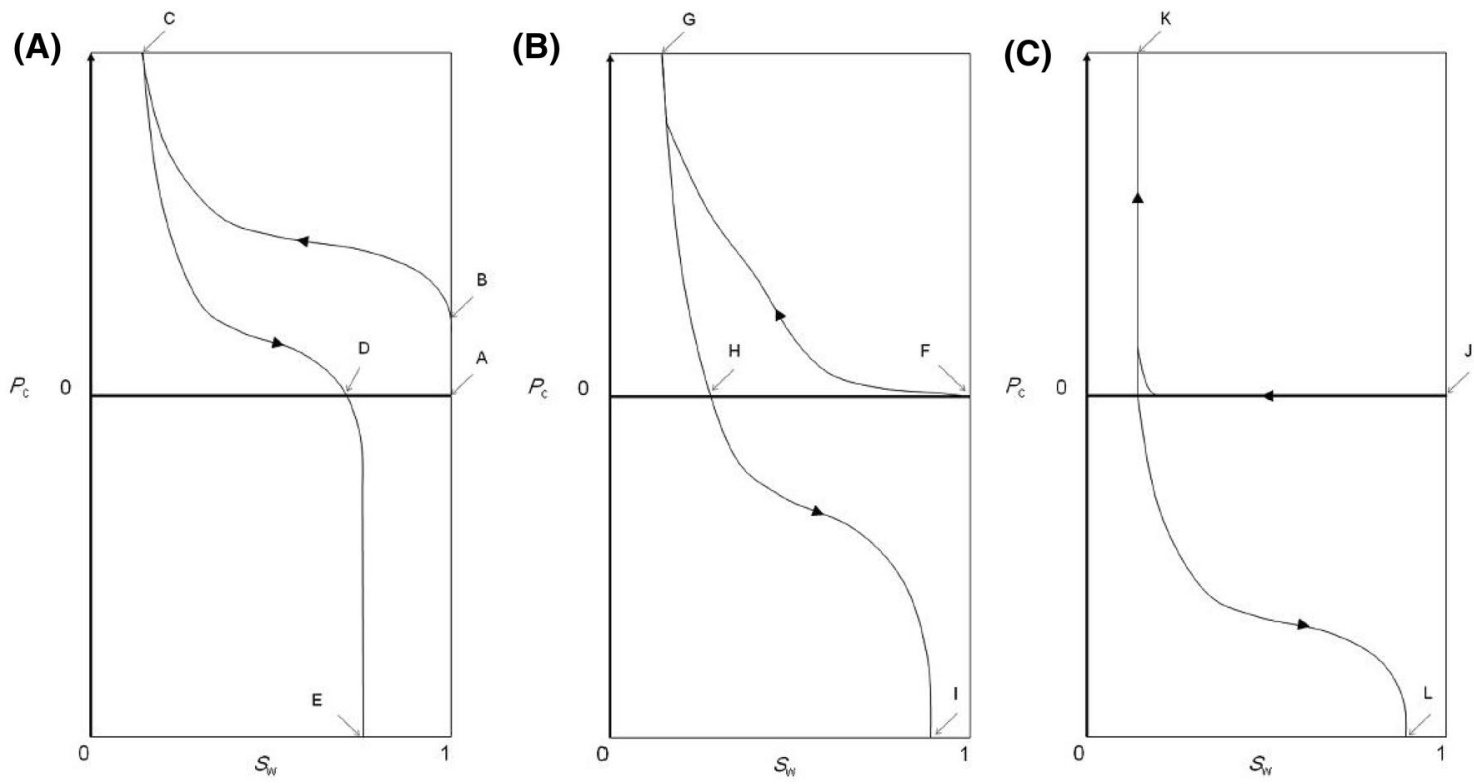

Fig. 4 Capillary pressure $(P c)$-water saturation $(S w)$ profiles for a a strong water-wet system, $\mathbf{b}$ intermediate-wet system, and $\mathbf{c} \mathrm{CO}_{2}$-wet system (Iglauer et al. 2015)

(A)

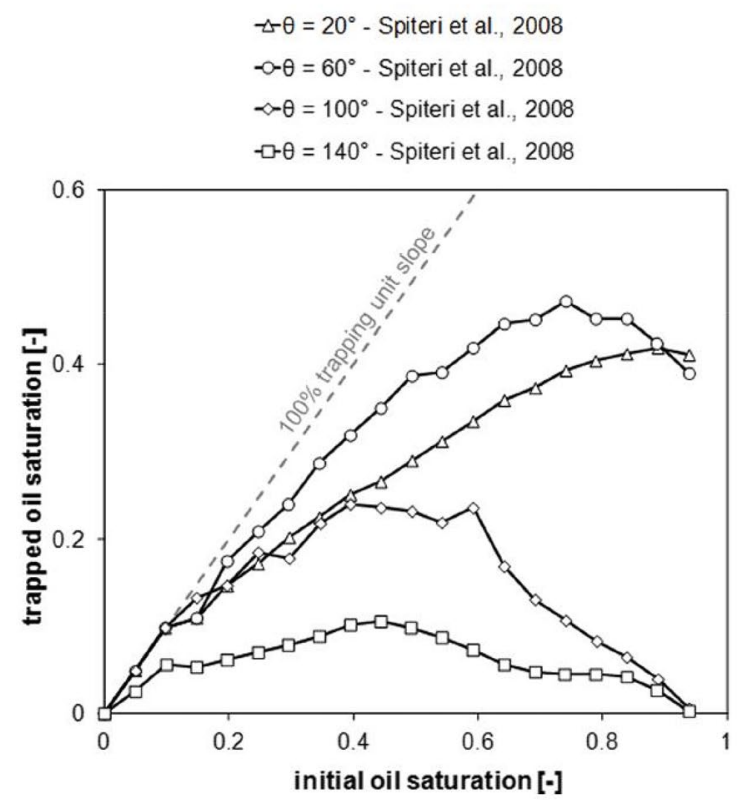

(B) $\triangle$ Berea sandstone - Pentland et al., 2011

B Berea sandstone - Krevor et al., 2012

^Mt. Simon sandstone - Krevor et al., 2012

A Paaratte sandstone - Krevor et al., 2012

$\triangle$ Tuscaloosa sandstone - Krevor et al., 2012

A Berea sandstone - Akbarabadi and Piri, 2013

\ Nuggent sandstone - Akbarabadi and Piri, 2013

- Indiana limestone - El-Maghraby and Blunt, 2013

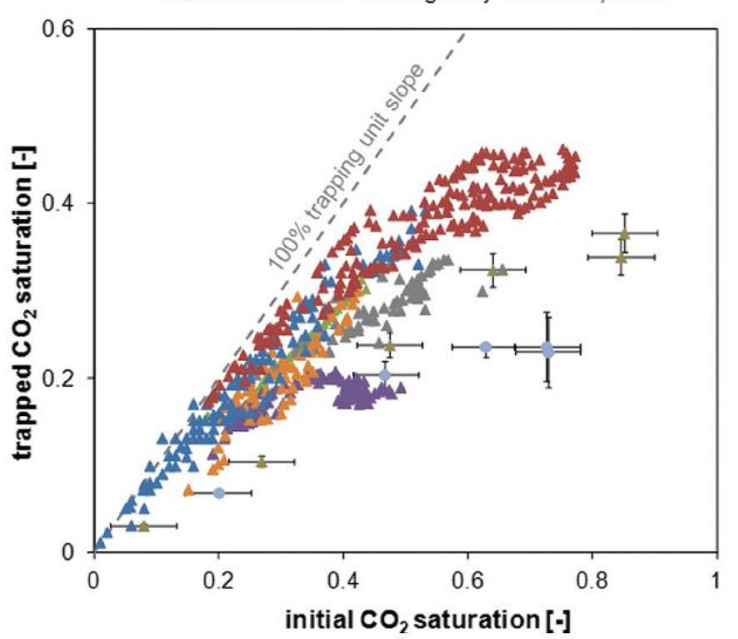

Fig. 5 Residual saturation profiles at initial conditions based on a pore-network modeling and b laboratory measurements. (Iglauer et al. 2015) 
Fig. 6 Comparisons between brine film drainage and rewetting measurements at different capillary potentials of model predictions for adsorbed film thicknesses (Kim et al. 2013)

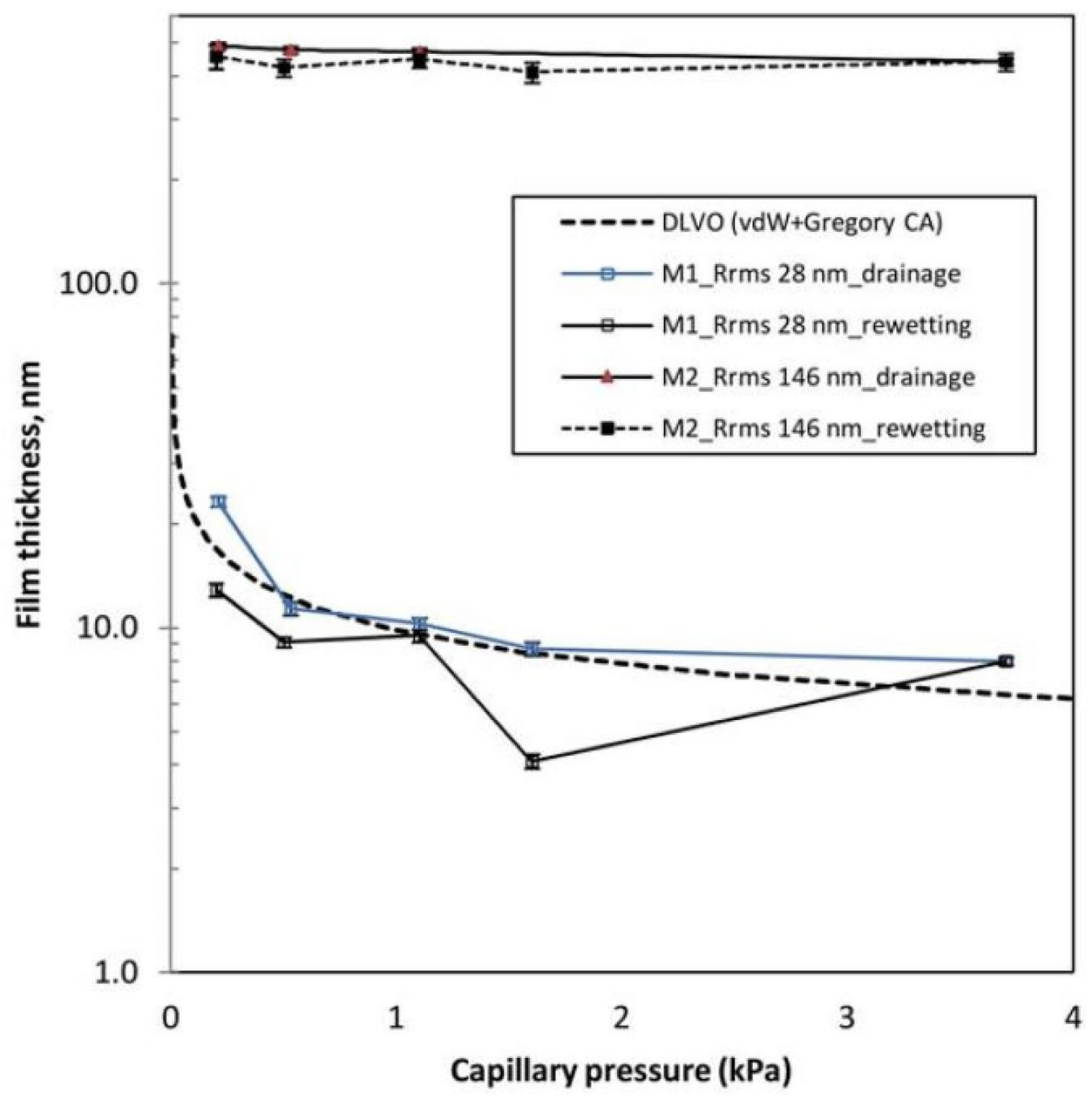

They noticed that within the small range of tested capillary potentials $(0.18-3.7 \mathrm{kPa})$, brine film thicknesses on mica were governed by surface roughness and only weakly influenced by capillary potentials. They compared drainage and rewetting isotherms, and observed film thickness hysteresis that is indicative of changes in mica wettability; see Fig. 6.

\section{Challenges associated with $\mathrm{CO}_{2}$ sequestration}

Several challenges are associated with the implementation of a $\mathrm{CO}_{2}$ sequestration project. It is difficult to list all the challenges as part of this review. Thus, the problems associated with the injection of $\mathrm{CO}_{2}$ are considered. Pipelines are the most commonly used methods for the transport of high volumes of $\mathrm{CO}_{2}$ over long distances (Leung et al. 2014). One of the major issues associated with the injection of $\mathrm{CO}_{2}$ is the acidic nature of the gas, which may lead to corrosion of the pipelines. Another issue with $\mathrm{CO}_{2}$ injection is that $\mathrm{CO}_{2}$ can cause significant asphaltene deposition, which may lead to the plugging of the reservoir/aquifer and the blocking of the transportation pipeline (Zanganeh et al. 2012).

\section{Problems associated with the corrosive nature of $\mathrm{CO}_{2}$}

The chemical reaction of $\mathrm{CO}_{2}$ with water forms carbonic acid; this acid lowers the $\mathrm{pH}$ of the aqueous phase, resulting in severe internal corrosion of the pipes. The carbonic acid attacks the iron to form soluble iron bicarbonate, which upon heating releases $\mathrm{CO}_{2}$ and an insoluble iron carbonate or hydrolyzes to iron oxide. If $\mathrm{H}_{2} \mathrm{~S}$ is present, it will react with the iron oxide to form iron sulfide. High liquid velocities can erode the protective iron sulfide film with resulting higher corrosion rates. Increased corrosion leads to severe pitting attack, which is one of the predominant causes of pipeline failures.

It is, therefore, important that an effective pipeline management program is carried out to minimize the risks and consequential health, environmental, and economic impact of corroded pipeline failures. Moloney et al. (2008) explained the corrosion effects on the gas hydrates and how 
to control it due to wet sour gas transmission systems. To prevent corrosion and corresponding operational issues associated with the presence of water in the $\mathrm{CO}_{2}$ stream, corrosion inhibitors should be added to help protect carbon steel pipelines from metal degradation. In addition, the corrosion inhibitor should be compatible with the system.

Loizzo (2008) observed the effects of $\mathrm{CO}_{2}$ injection on cementation. The evaluation was performed precisely and clearly demonstrated that cement and steel can be corroded by $\mathrm{CO}_{2}$ which will be accelerated in the case of bad cement jobs. A good planning and execution for cementing a well was conducted where a centralizer was used for each joint of casing. This is not widespread practice, especially for vertical wells. The plan was to ensure good isolation for $\mathrm{CO}_{2}$ operations. However, the hole was not perfectly vertical; deviations $<2^{\circ}$ mandated the use of squeeze cements prior the $\mathrm{CO}_{2}$ injection.

Nelson et al. (1990) indicated that $\mathrm{CO}_{2}$-laden waters can destroy the structural integrity of set Portland cements. The chemistry of this reaction is as follows:

$$
\mathrm{CO}_{2}+\mathrm{H}_{2} \mathrm{O} \leftrightarrow \mathrm{H}_{2} \mathrm{CO}_{3} \leftrightarrow \mathrm{H}^{+}+\mathrm{HCO}_{3}^{-}
$$$$
\mathrm{Ca}(\mathrm{OH})_{2}+\mathrm{H}^{+}+\mathrm{HCO}_{3}^{-} \rightarrow \mathrm{CaCO}_{3}+2 \mathrm{H}_{2} \mathrm{O}
$$

$\mathrm{C}$ - S - $\mathrm{H}$ phase $+\mathrm{H}^{+}+\mathrm{HCO}_{3}^{-} \rightarrow \mathrm{CaCO}_{3}+$ amorphous silica gel

In the first reaction, approximately $1 \%$ of the dissolved $\mathrm{CO}_{2}$ reacts with water to form carbonic acid. As the $\mathrm{CO}_{2}$-laden water diffuses into the cement matrix, the dissociated acid is free to react with the free calcium hydroxide (reaction 2) and the $\mathrm{C}-\mathrm{S}-\mathrm{H}$ phase (reaction 3). As $\mathrm{CO}_{2}$-laden water continues to invade the matrix, another equilibrium is established.

$\mathrm{CO}_{2}+\mathrm{H}_{2} \mathrm{O}+\mathrm{CaCO}_{3} \rightarrow \mathrm{Ca}\left(\mathrm{HCO}_{3}\right)_{2}$

$$
\mathrm{Ca}\left(\mathrm{HCO}_{3}\right)_{2}+\mathrm{Ca}(\mathrm{OH})_{2} \leftrightarrow 2 \mathrm{CaCO}_{3}+\mathrm{H}_{2} \mathrm{O}
$$

In the presence of excess $\mathrm{CO}_{2}$ (reaction 4), calcium carbonate is converted to water soluble calcium bicarbonate, which can migrate out of the cement matrix. In reaction 5 , the dissolved calcium bicarbonate can react with calcium hydroxide, forming calcium carbonate and water. The produced water can then dissolve more calcium bicarbonate. The net result is a leaching of cementitious material from the cement matrix, an increase in porosity and permeability, and a decrease of compressive strength. Downhole, this means loss of casing protection and zonal isolation. $\mathrm{CO}_{2}$ corrosion of Portland cements is thermodynamically favored and cannot be prevented, although it may be mitigated by the use of synthetic cement, which is expensive and may not be feasible for most $\mathrm{CO}_{2}$ flooding or $\mathrm{CO}_{2}$ sequestration projects. Instead, it is more practical to lower the degradation rate of Portland cement systems.

Le Guen et al. (2008) indicated that $\mathrm{CO}_{2}$ injection can create preferential channels over time, allowing migration of $\mathrm{CO}_{2}$ from the reservoir to shallower formations, for example, in aquifers and/or to the surface. Possible local impacts resulting from injection operations or leakage could be:

- Acidification of potable aquifers, which can make water unsuitable for consumption.

- Acidification of soils with impact on vegetation or agriculture.

- Accumulations of gaseous $\mathrm{CO}_{2}$ at the surface affecting human health and/or the environment.

- Increasing risks associated with $\mathrm{CO}_{2}$ leakage over the storage period.

Nygaard et al. (2014) studied the effects of dynamic loading on wellbore leakage. They specified approximately 1000 wells in the Wabamun zone (near Wabamun Lake, Alberta, Canada) to determine the leakage pathway of $\mathrm{CO}_{2}$. They observed that the main reason for this leakage was the well design, well scenario, and offset data of the area. They concluded that thermal and pressure change could lead to near wellbore stress reduction, which might lead to a change in the cement properties such as increased Young's modulus and Poisson's ratio, causing cementation design failures.

\section{Asphaltene precipitation}

$\mathrm{CO}_{2}$ can be stored in high-viscosity and high-density hydrocarbon reservoirs where the oil cannot be easily recovered due to low mobility of the fluid (Alboudwarej et al. 2006; Cavallaro et al. 2008; Hascakir 2017). This, however, may lead to asphaltene dropout. Novosad et al. (1990) developed a model to predict the asphaltene deposition rate during $\mathrm{CO}_{2}$ injection in a $29^{\circ}$ API gravity reservoir. Their experimental results demonstrated that a considerable amount of solid deposit (consisting of Asphaltene, wax, and trapped oil) formed in the wellbore equipment and down hole facilities.

Kokal and Sayegh (1995) discussed the factors contributing to asphaltene precipitation, such as nature of rock and matrix, asphaltene and resin composition of the reservoir oil, formation brine and its composition, the nature of the injection gas, the presence of contaminants in the injection gas, temperature, and pressure conditions. They indicated that this problem can be best observed on the Weyburn reservoir and examined the effects of operating pressure, $\mathrm{CO}_{2}$ concentration, brine formation, and contaminants in $\mathrm{CO}_{2}$ such as methane and nitrogen on asphaltene flocculation/ 
precipitation. Weyburn is a light oil reservoir $\left(28^{\circ}-35^{\circ}\right.$ API gravity) located in south-eastern Saskatchewan. It is characterized by a higher permeability Vuggy zone at the bottom and a Marly zone at the top. The injected $\mathrm{CO}_{2}$ is more likely to contact and mobilize the reservoir oil in the Marly zone, which could be the more susceptible area for asphaltene deposition.

Zanganeh et al. (2012) used a high-pressure cell and image processing techniques to visualize the asphaltene deposition process and concluded that as the pressure increases, the area of deposition increases. They also concluded that an increase in temperature allows the asphaltene particles to flocculate and form larger particles.
Table 3 Worldwide $\mathrm{CO}_{2}$ storage projects

\begin{tabular}{llll}
\hline Date & Name & Location & $\begin{array}{l}\mathrm{CO}_{2} \text { sequestration rate } \\
(1000 \text { kg/year })\end{array}$ \\
\hline 1996 & Sleipner & Norway & 1 million \\
2000 & Weyburn & Canada & $500,000+$ \\
2004 & In Salah & Algeria & 1.2 million \\
2007 & Otway Basin & Australia & 109,500 total \\
$2007-2011$ & Snøhvit & Norway & 0.7 million \\
$2018-$ present & Alberta Carbon Trunk Line & Canada & 14.6 million \\
- & Boundary Dam & Canada & - \\
- & Cranfield & USA & - \\
$2004-2006$ & Frio Brine & USA & - \\
$2008-2009$ & Ketzin & Germany & 67,271 \\
2011 & Citronelle & USA & - \\
2013 & Northern Reef Trend & USA & - \\
2013 & Port Arthur & USA & - \\
2006 & Zama & Canada & - \\
$2010-2014$ & Ordos & China & - \\
\hline
\end{tabular}

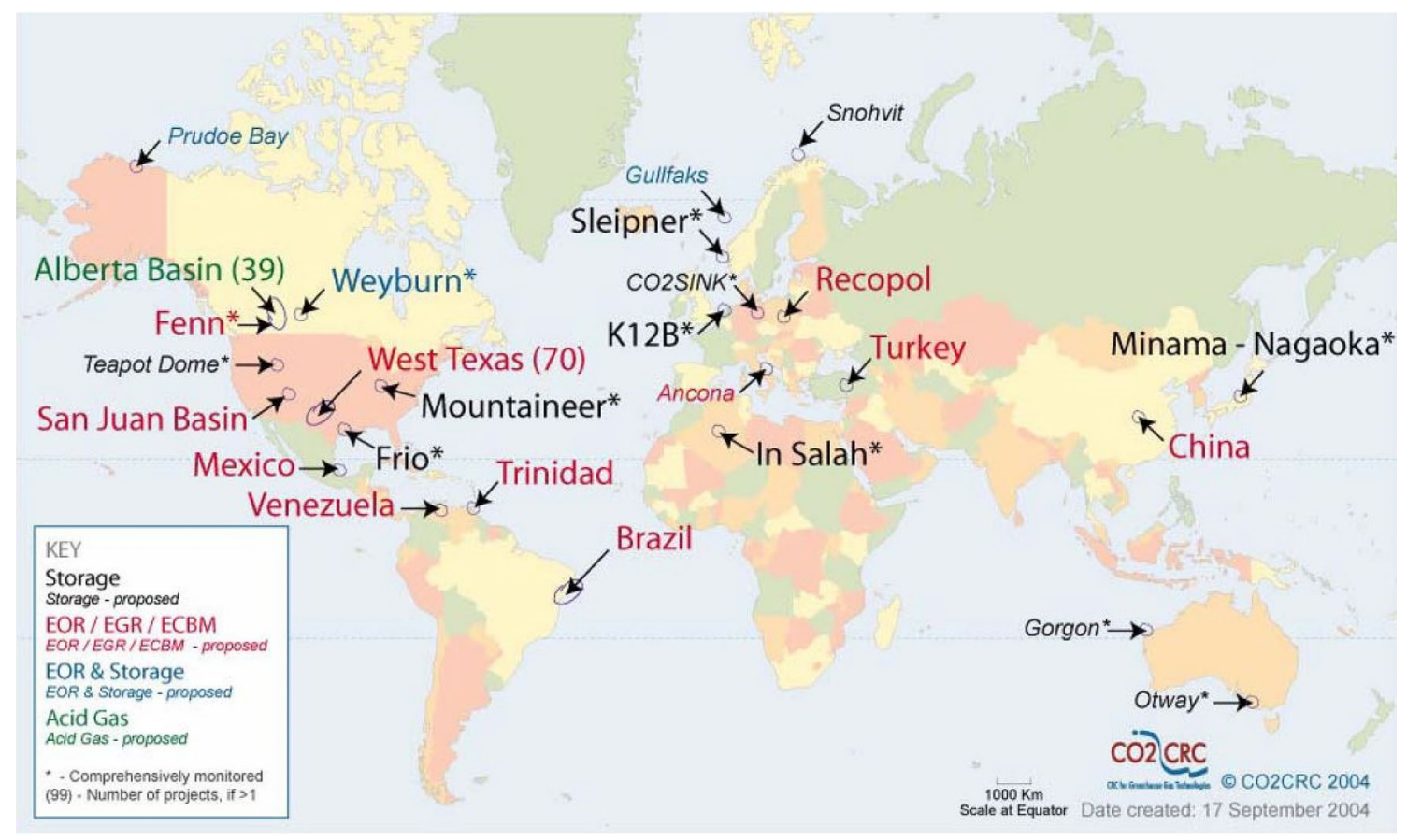

Fig. 7 Field sites focused on active or underway $\mathrm{CO}_{2}$ storage projects (Sengul 2006) 


\section{Field studies}

$\mathrm{CO}_{2}$ storage can take place in a variety of subsurface reservoirs including but not limited to oil and gas reservoirs, aquifers, salt caverns, deep coal seams, deep ocean, and mineral carbonation (Voormeij et al. 2002; Shukla et al. 2010). Injecting $\mathrm{CO}_{2}$ into hydrocarbon reservoirs may result in the added benefit of increasing oil production, which lies in the domain of Enhanced Oil Recovery (EOR). Thus, $\mathrm{CO}_{2}$ EOR not only protects the environment but also improves oil recovery.

$\mathrm{CO}_{2}$ storage in geological formations was first proposed in the 1970s (Holloway and Savage 1993) and practically implemented during the 1990s (Benson et al. 2006). There are several $\mathrm{CO}_{2}$ storage projects in operation worldwide (Table 3 ). The active $\mathrm{CO}_{2}$ storage projects are schematically presented in Fig. 7.

\section{Sleipner Project}

Sleipner is known as the first $\mathrm{CO}_{2}$ sequestration project in the North Sea, as shown in Fig. 8. Inspired by the carbon tax policy of Norway, it started in 1996 and injected about $10 \mathrm{Mt}$ of $\mathrm{CO}_{2}$ by mid-2008 into the formation (Shukla et al. 2010). The target formation is Utsira, comprising 200-300 m thick sandstone along with mudstone layers which are relatively thinner. The sandstone layer is a saline aquifer. There is a 200-300 m impermeable layer of cap-rock (shale) which prevents injected $\mathrm{CO}_{2}$ from rising to the surface (Bachu 2000; Nooner et al. 2007; Lindeberg et al. 2001; Mackenzie et al. 2001).

Sleipner did not encounter major operational issues and is considered the most successful $\mathrm{CO}_{2}$ sequestration project. Thus, $\mathrm{CO}_{2}$ storage is considered feasible since significant problems did not arise in the carbon capture plant or injection wells (Korbøl and Kaddour 1995; Qi et al. 2009; Sengul 2006; Torp and Gale 2004; Yamamoto et al. 2004).

\section{Weyburn Project}

Another monumental project is the Weyburn Project situated in the Williston Basin in Saskatchewan, Canada. It started in 2000 and aimed to inject $\mathrm{CO}_{2}$ into the oil fields for EOR. The Weyburn field is a Midale carbonate reservoir consisting of two different important units. The lower unit is known as Vuggy and the upper zone is named Marly. The Vuggy and Marly zones contain limestone and dolomite, respectively (Yamamoto 2004; Malik and Islam 2000). Further, the two
Fig. $8 \mathrm{CO}_{2}$ storage project of Sleipner in Norway (Sengul 2006)

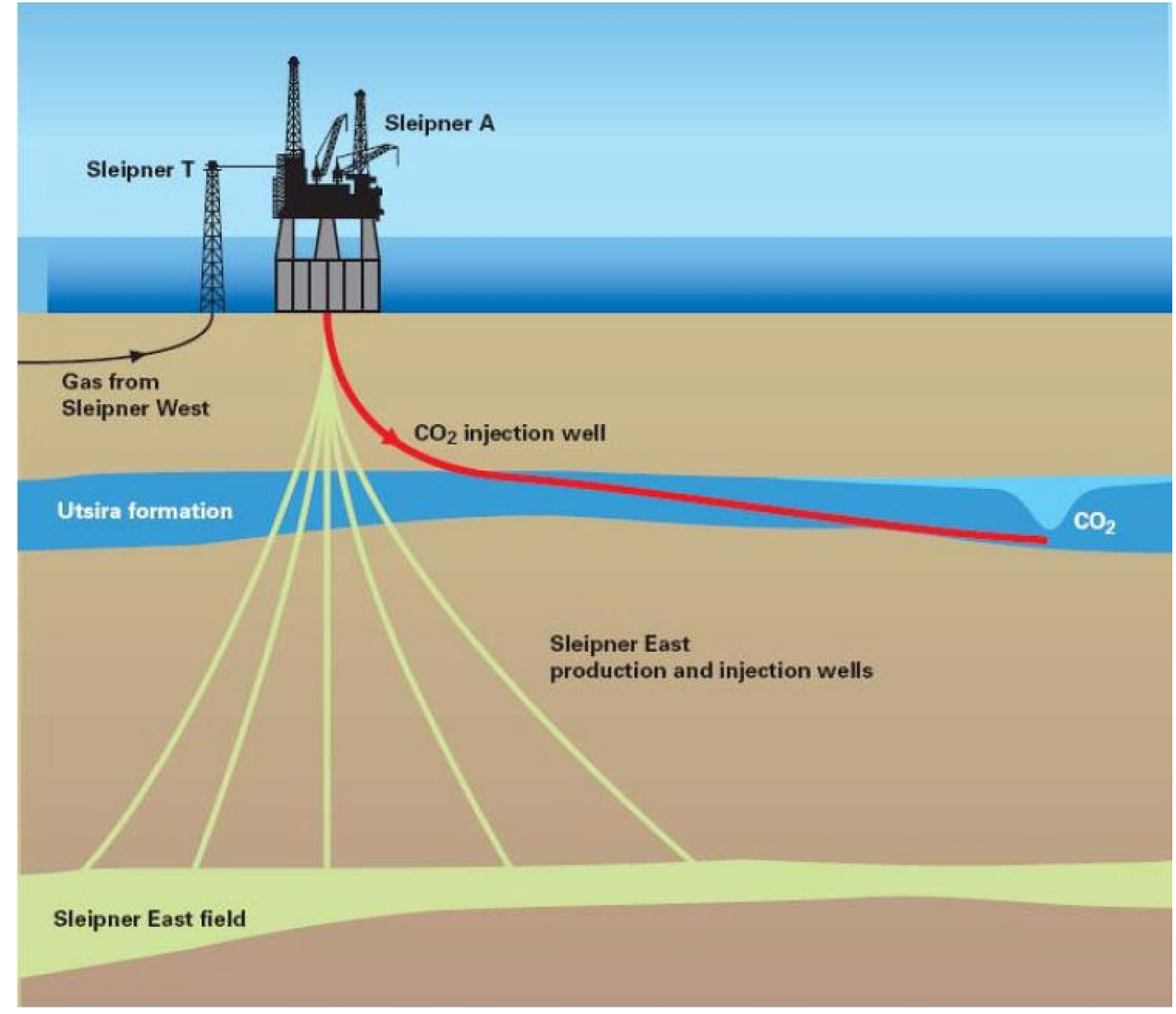


zones are trapped by a caprock (anhydrite). Detailed characteristics of this field are provided by Burrowes (2001).

The Dakota Gasification Company provides $\mathrm{CO}_{2}$ for injection into the Utsira formation at 3000-5000 t per day (Shukla et al. 2010). The estimated lifespan of this EOR project is 20-25 years, and it is predicted that by 2030 , approximately $20 \mathrm{Mt}$ of $\mathrm{CO}_{2}$ will be deposited in the field (Bachu 2000).

\section{In Salah Project}

In 2004, British Petroleum (BP) and Statoil jointly started a $\mathrm{CO}_{2}$ sequestration project. The project name is In Salah and is situated in Algeria. It is an operational gas field and sources $\mathrm{CO}_{2}$ from the In Salah oil field (Ringrose et al. 2013). The $\mathrm{CO}_{2}$ injected into the aquifer leads to a storage of 1.2 Mt per annum (Schaefer et al. 2000). The $\mathrm{CO}_{2}$ is fed into the carboniferous sandstone formation which is $20 \mathrm{~m}$ in thickness located near the Krechba gas field. This field consists of $3 \mathrm{CO}_{2}$ gas injection wells and 4 gas production wells (Rutqvist et al. 2009). The total capacity of the formation is approximately $17 \mathrm{Mt}$ of $\mathrm{CO}_{2}$ (Mathieson et al. 2011). Between the period of 2004 and 2011, $4 \mathrm{Mt}$ of $\mathrm{CO}_{2}$ was injected into the Krechba formation (Mathieson et al. 2011, 2009; Rutqvist et al. 2009).

Advanced techniques like micro-seismic and time-lapse seismic data were utilized to monitor the project and to update the several models related to this project, which includes geomechanical, geological, and dynamic models. Because of the cap-rock integrity, the injection was suspended in mid-2011 (Pamukcu et al. 2011; Bhowmik et al. 2011). Migration of $\mathrm{CO}_{2}$ from the reservoir to the overburden rock was undertaken, and importantly, leakage of $\mathrm{CO}_{2}$ into the atmosphere did not occur during this transition (White et al. 2014). The In Salah project is instrumental in providing data on $\mathrm{CO}_{2}$ injection in low permeability elastic reservoirs.

\section{Snøhvit Project}

The Norway based Snøhvit Project, started in 2007, is run by Statoil ASA and others (Negrescu 2007). It is known as the first offshore project where crude oil is extracted without using conventional offshore equipment. In the Snøhvit project, $\mathrm{CO}_{2}$ is primarily obtained from an LNG processing plant by the scrubbing method (Chiaramonte et al. 2015), transported through pipelines and injected into the $2600 \mathrm{~m}$ deep sandstone reservoir with a thickness of 45-75 m (MIT. Carbon Capture and Sequestration Technologies 2015). The storage capacity of this reservoir was initially determined between 31 and $40 \mathrm{Mt}$, although later, it was determined that the capacity was over estimated and drilling of new wells and fracturing operations are under consideration to increase the existing capacity (MIT. Carbon Capture and Sequestration Technologies 2015). Approximately 0.7 Mt of $\mathrm{CO}_{2}$ was stored per annum.

\section{Alberta Carbon Trunk Line Project}

The Alberta Carbon Line Project by Enhance Energy Inc. is presently one of the giant CCS projects, with a pipeline network of approximately 149 miles, and has the capacity to store up to $14.6 \mathrm{Mt}$ of $\mathrm{CO}_{2}$ per annum. $\mathrm{CO}_{2}$ is mainly obtained from the North West Sturgeon Refinery and Agrium Fertilizer plant (Cole and Itani 2013). The total storage capacity was initially estimated as $2 \mathrm{Gt}$, and the injection started in 2018 (GCCSI 2017).

\section{Otway Basin Project}

The Otway Basin Project, a pilot project situated in Australia and initiated in 2008, is considered the largest onshore CSS project (Ranasinghe 2013; Sharma et al. 2011). The $\mathrm{CO}_{2}$ is obtained from $\mathrm{CO}_{2}$-rich natural gas (Sharma et al. 2011) and injected into a low pressured gas bearing formation at a depth of $4000 \mathrm{~m}$ (Hortle et al. 2011). The effects of this $\mathrm{CO}_{2}$ injection on soil and the surrounding environment was examined by Schacht and Jenkins (Schacht and Jenkins 2014). Different tests were carried out and it was concluded that the source of the $\mathrm{CO}_{2}$ is biogenic and sufficiently shallow that the impact on the environment is insignificant. Studies are still ongoing to determine the different geomechanical and seismic hazards associated with $\mathrm{CO}_{2}$ injection (Stirling et al. 2011).

\section{Boundary Dam Project}

The Boundary Dam Project by SaskPower is situated in Estevan, Canada and is the first commercial scale CCS project worldwide. The project has the capacity to inject $1 \mathrm{Mt}$ of $\mathrm{CO}_{2}$ per annum. Ninety percent of the $\mathrm{CO}_{2}$ is transported via pipeline to the Weyburn field where it is used for $\mathrm{CO}_{2}$-EOR while the remaining gas is reserved in a sandstone formation. The deepest parts of the formation were selected for $\mathrm{CO}_{2}$ injection as they have a greater storage capacity. Different tests were performed to examine complex storage suitability and no hazardous impact was observed (Worth et al. 2014).

\section{Cranfield Project}

The Cranfield Project is situated in Mississippi, USA, in which $1.5 \mathrm{Mt}$ of $\mathrm{CO}_{2}$ obtained from the Jackson Dome is annually injected into a $15 \mathrm{~m}$ thick and $3000 \mathrm{~m}$ deep

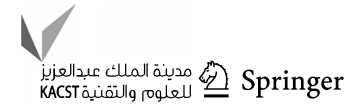


heterogeneous sandstone formation (MIT. Carbon Capture and Sequestration Technologies 2015). Anderson et al. (2017) carried out extensive studies to inspect for $\mathrm{CO}_{2}$ leakage, and no traces of $\mathrm{CO}_{2}$ leakage from the subsurface were detected.

\section{Frio Brine Pilot Project}

$\mathrm{CO}_{2}$ was injected into the Frio sandstone reservoir in two stages; $1600 \mathrm{t}$ of $\mathrm{CO}_{2}$ was injected in the first stage in 2004, while $1600 \mathrm{t}$ of $\mathrm{CO}_{2}$ was fed in the second stage in 2006 (Hovorka 2006). Before commencement of this project, $\mathrm{CO}_{2}$ injection was carried out in hydrocarbon bearing reservoirs only (Atkinson 2014), although the primary project motives were to inject $\mathrm{CO}_{2}$ into brine formation without inducing any hazardous impact to the surrounding environment and analyze the behavior of stored $\mathrm{CO}_{2}$ (CSLF 2010). Continuous leakage monitoring of the storage area was proposed at the end of the project to evaluate the possibility of large-scale applications in the future (Hovorka 2006).

\section{Ketzin Project}

The Ketzin Project is situated in Ketzin, Germany, was initiated in 2008 and completed in 2009. The aim of this project was to inject $\mathrm{CO}_{2}$ into the subsurface which can be monitored for future policies and to reveal underground information. The Stuttgart formation which is sandstone was utilized to store $\mathrm{CO}_{2}$ (Guen et al. 2011; Möller et al. 2014; Streibel et al. 2014).

The $\mathrm{CO}_{2}$ was transferred via pipeline and injected into the sandstone formation aquifer. In this project, $67,271 \mathrm{t}$ of $\mathrm{CO}_{2}$ was successfully deposited in the subsurface.

\section{Citronelle Project}

The Citronelle Project started in 2011 and is situated at the Citronelle oilfield, USA. The $\mathrm{CO}_{2}$ for this project is obtained from the plant, transported through a pipeline and injected into a $335 \mathrm{~m}$ thick saline aquifer (Koperna et al. 2014). Chen and Liu (2011) used seismic measurements to study the geological changes in the storage zone and examine pre- and post-injection $\mathrm{CO}_{2}$ migration; no traces of $\mathrm{CO}_{2}$ leakage were detected so far (Citronelle Project NETL 2017).

\section{Northern Reef Trend Project}

The $\mathrm{CO}_{2}$ for the Northern Reef Trend Project is obtained from the plant, conveyed through a pipeline and injected into a carbonate depleted reservoir which was previously under water flooding. This project was initiated in 2013 and it aims to store $1 \mathrm{Mt}$ of $\mathrm{CO}_{2}$ within a span of 3 to 5 years.
Investigations are currently underway to analyze the behavior of the fed $\mathrm{CO}_{2}$ and to determine the $\mathrm{CO}_{2}$ storage capability in the reservoir (Kelley et al. 2014).

\section{Port Arthur Project}

This project is located in Port Arthur, USA and began in January 2013. The $\mathrm{CO}_{2}$ for this project is obtained from a refinery, transported in two stages via pipelines, and used for the $\mathrm{CO}_{2}$-EOR process. From commencement till May 2013, approximately $222,000 \mathrm{t}$ of $\mathrm{CO}_{2}$ were injected, resulting in 1.6 to 3.1 million bbl of additional oil recovery (Eng 2014).

\section{Zama Project}

The Zama Project began in 2006 with the objective of testing acid gas injection to enhance oil recovery and minimize the cost of $\mathrm{CO}_{2}$ purification. The gas stream consists of $70 \%$ $\mathrm{CO}_{2}$ and $30 \% \mathrm{H}_{2} \mathrm{~S}$ which is obtained from a plant and fed into a $1500 \mathrm{~m}$ deep reservoir. The project is expected to store $1.3 \mathrm{Mt}$ of $\mathrm{CO}_{2}$ and $0.5 \mathrm{Mt}$ of $\mathrm{H}_{2} \mathrm{~S}$ over a period of 18 years. As a result of injecting of $80,000 \mathrm{t}^{\circ} \mathrm{H}_{2} \mathrm{~S}, 35,000$ barrels of additional oil was produced (Trivedi et al. 2007). Bennion and Bachu (2008) carried out extensive studies to analyze the effects of acid gas injection on reservoir conditions and the surrounding environment and found that $\mathrm{CO}_{2}-\mathrm{H}_{2} \mathrm{~S}$ was both economically and environmentally favorable to a certain limit. Moreover, further experimental and numerical studies were proposed to determine the short-term and longterm effects of acid gas injection on reservoir quality.

\section{Ordos Project}

The Ordos Project is situated in China, started at the pilot scale level in 2010 and will be implemented at the commercial scale by 2020 . The source of injected $\mathrm{CO}_{2}$ is a coal liquefaction plant which emits $3.6 \mathrm{Mt}$ of $\mathrm{CO}_{2}$ annually. The $\mathrm{CO}_{2}$ is transported through a pipeline and injected into a saline aquifer; since commencement till 2014, approximately $150,000 \mathrm{t}$ of $\mathrm{CO}_{2}$ had been injected (Luo et al. 2014). A monitoring system was used (Zhao et al. 2017) to trace $\mathrm{CO}_{2}$ migration and it was observed that the fed $\mathrm{CO}_{2}$ was contained inside the $450 \mathrm{~m}$ injection well. Moreover, no leakage of $\mathrm{CO}_{2}$ was detected.

\section{Conclusion and recommendations}

In this study, we discussed the various efforts by different researchers to study $\mathrm{CO}_{2}$ storage in different underground storage types. Specifically, the various research efforts based 
on experimental, modeling and field studies were reviewed. In the study, we determined that effects such as lithology, capillarity, and chemical reactions significantly influence the behavior of $\mathrm{CO}_{2}$ during the sequestration process. Additionally, it was identified that the depleted (or saline) reservoir offers the best storage medium for $\mathrm{CO}_{2}$. After the injection of $\mathrm{CO}_{2}$ within the subsurface, understanding the interaction between the different fluids and the rocks and the geologic and geochemical characteristic of reservoir rock types are needed for a successful modeling study. In this study, it was observed that there exist various successful field studies aimed at storing $\mathrm{CO}_{2}$ underground. Examples of such projects include In Salah and Sleipner in Algeria and Norway, respectively. Though other unsuccessful field studies exist, it is worthy to mention that proper design, injection, and monitoring of these $\mathrm{CO}_{2}$ storage projects will give additional insights into this highly effective and common method of $\mathrm{CO}_{2}$ storage.

Acknowledgements The authors acknowledge the support provided by the College of Petroleum Engineering and Geosciences (CPG) at King Fahd University of Petroleum and Minerals, Saudi Arabia through the grant SF20006.

Funding There is no funding party for the research of interest.

\section{Compliance with ethical standards}

Conflict of interest On behalf of all the co-authors, the corresponding author states that there is no conflict of interest.

Open Access This article is licensed under a Creative Commons Attribution 4.0 International License, which permits use, sharing, adaptation, distribution and reproduction in any medium or format, as long as you give appropriate credit to the original author(s) and the source, provide a link to the Creative Commons licence, and indicate if changes were made. The images or other third party material in this article are included in the article's Creative Commons licence, unless indicated otherwise in a credit line to the material. If material is not included in the article's Creative Commons licence and your intended use is not permitted by statutory regulation or exceeds the permitted use, you will need to obtain permission directly from the copyright holder. To view a copy of this licence, visit http://creativecommons.org/licenses/by/4.0/.

\section{References}

Ajayi T, Awolayo A, Gomes JS, Parra H, Hu J (2019) Large scale modeling and assessment of the feasibility of $\mathrm{CO}_{2}$ storage onshore Abu Dhabi. Energy 185:653-670. https://doi.org/10.1016/j.energ y.2019.07.052

Alboudwarej H, Felix J, Taylor S (2006) Highlighting heavy oil. Oilfield Rev 18(2):34-53

Ampomah W, Balch R, Cather M, Rose-Coss D, Dai Z, Heath J, Dewers T, Mozley P (2016) Evaluation of $\mathrm{CO}_{2}$ storage mechanisms in $\mathrm{CO}_{2}$ enhanced oil recovery sites: application to morrow sandstone reservoir. Energy Fuels 30:8545-8555. https://doi. org/10.1021/acs.energyfuels.6b01888
Anderson JS, Romanak KD, Yang C, Lu J, Hovorka SD, Young MH (2017) Gas source attribution techniques for assessing leakage at geologic $\mathrm{CO}_{2}$ storage sites: evaluating a $\mathrm{CO}_{2}$ and $\mathrm{CH}_{4}$ soil gas anomaly at the Cranfield $\mathrm{CO}_{2}$-EOR site. Chem Geol 454:93-104. https://doi.org/10.1016/j.chemgeo.2017.02.024

Arif M, Barifcani A, Iglauer S (2016) Solid/ $\mathrm{CO}_{2}$ and solid/water interfacial tensions as a function of pressure, temperature, salinity and mineral type: Implications for $\mathrm{CO}_{2}$-wettability and $\mathrm{CO}_{2}$ geo-storage. Int J Greenh Gas Control 53:263-273. https://doi. org/10.1016/j.ijggc.2016.08.020

Atkinson W (2014) Carbon capture and sequestration: real progress taking place. Pollut Eng 46:30-32. Google Search [WWW Document], n.d. https://www.google.com/search?q=Atkin son+W.+Carbon+capture+and+sequestration $\% 3 \mathrm{~A}+$ Real+progr ess+taking + place .+Pollut+Eng +2014\%3B 46\%3A302.\&oq $=$ Atkin son + W. + Carbo $n+$ capture + and + seque stration $\% 3 \mathrm{~A}+$ Real+progress +taking + place.+Pollu $\mathrm{t}+$ Eng $+2014 \% 3 \mathrm{~B} 46 \% 3 \mathrm{~A} 30-2 . \&$ aqs $=$ chrome..69i57.1267866j0j $9 \&$ sourceid=chrome \&ie=UTF-8. Accessed 16 Nov 19

Bachu S (2000) Sequestration of $\mathrm{CO}_{2}$ in geological media: criteria and approach for site selection in response to climate change. Energy Convers Manag 41:953-970. https://doi.org/10.1016/ S0196-8904(99)00149-1

Bao K, Yan M, Allen R, Salama A, Lu L, Jordan KE, Sun S, Keyes D (2016) High-performance modeling of carbon dioxide sequestration by coupling reservoir simulation and molecular dynamics. SPE J Soc Pet Eng. https://doi.org/10.2118/163621-pa

Bennion B, Bachu S (2008) Drainage and imbibition relative permeability relationships for supercritical $\mathrm{CO}_{2}$ /brine and $\mathrm{H}_{2} \mathrm{~S} /$ brine systems in intergranular sandstone, carbonate, shale, and anhydrite rocks. SPE Reserv Eval Eng 11:487-496. https://doi. org/10.2118/99326-PA

Benson SM (2006) Monitoring carbon dioxide sequestration in deep geological formations for inventory verification and carbon credits. In: SPE annual technical conference and exhibition, Society of Petroleum Engineers

Bhowmik S, Srinivasan S, Bryant SL (2011) Inferring migration of $\mathrm{CO}_{2}$ plume using injection data and a probabilistic history matching approach. Energy Procedia 4:3841-3848

Bryant SL, Lakshiminarasimhan S, Pope GA (2006) Buoyancy-dominated multiphase flow and its impact on geological sequestration of $\mathrm{CO}_{2}$, SPE 99938, SPE/DOE symposium on improved oil recovery, Tulsa, Okla

Burrowes $\mathrm{G}$ (2001) Investigating $\mathrm{CO}_{2}$ storage potential of carbonate rocks during tertiary recovery from a billion barrel oil field, Weyburn, Saskatchewan: part 2-reservoir geology (IEA Weyburn $\mathrm{CO}_{2}$ Monitoring and Storage Project). Summary of Investigations, vol 1, pp 2001-2004

Calabrese M, Masserano F, Blunt MJ (2005) Simulation of physical-chemical processes during carbon dioxide sequestration in geological structures. In: SPE annual technical conference and exhibition, Society of Petroleum Engineers. https://doi. org/10.2118/95820-MS

Cavallaro AN, Galliano GR, Moore RG, Mehta SA, Ursenbach MG, Zalewski E, Pereira P (2008) In situ upgrading of Llancanelo heavy oil using in situ combustion and a downhole catalyst bed. J Can Pet Technology 47(9):1-9

Chen S-E, Liu Y (2011) Geophysical sensing for $\mathrm{CO}_{2}$ sequestration and enhanced oil recovery. In: Contemporary topics on testing, modeling, and case studies of geomaterials, pavements, and tunnels, American Society of Civil Engineers, Reston, VA, pp 41-48. https://doi.org/10.1061/47626(405)6

Cherepovitsyn A, Ilinova A (2016) Ecological, economic and social issues of implementing carbon dioxide sequestration technologies in the oil and gas industry in Russia. J Ecol Eng 17(2):19-23

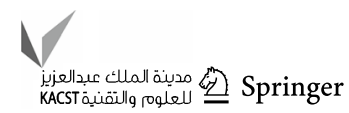


Chiaramonte L, White JA, Trainor-Guitton W (2015) Probabilistic geomechanical analysis of compartmentalization at the Snøhvit $\mathrm{CO}_{2}$ sequestration project. J Geophys Res Solid Earth 120:11951209. https://doi.org/10.1002/2014JB011376

Cinar Y, Riaz A, Tchelepi HA (2007). Experimental study of $\mathrm{CO}_{2}$ injection into saline formations. In: SPE annual technical conference and exhibition, Society of Petroleum Engineers. https://doi. org/10.2118/110628-MS

Citronelle Project Paluxy Formation, Citronelle, Alabama Southeast Regional Carbon Sequestration Partnership (2017) National Energy Technology Laboratory (NETL). https://www.netl.doe. gov/node/5921

Cole S, Itani S (2013) The Alberta carbon trunk line and the benefits of $\mathrm{CO}_{2}$. Energy Procedia 37:6133-6139. https://doi.org/10.1016/j. egypro.2013.06.542

Cooper C (2009) A technical basis for carbon dioxide storage. CPL Press, Cambridge

CSLF (2010) Strategic plan implementation report table of contents. Texas, USA. https://www.google.com/search?q=CSLF.+Strat egic+Plan+Imple mentation+Report+Table +of+Conte nts.+Texas $\% 2 \mathrm{C}+\mathrm{USA} \% 3 \mathrm{~A}+2010 \& \mathrm{oq}=\mathrm{CSLF} .+$ Strat egic+Plan+Imple mentation+Repor $\mathrm{t}+$ Table +of +Conte nts.+Texas\%2C+USA\%3A+2010\&aqs $=$ chrome..69i57.11147 98j0j9\&sourceid=chrome\&ie=UTF-8. Accessed 16 Nov 19

Delshad M, Kong X, Tavakoli R, Hosseini SA, Wheeler MF (2013) Modeling and simulation of carbon sequestration at Cranfield incorporating new physical models. Int J Greenh Gas Control 18:463-473. https://doi.org/10.1016/j.ijggc.2013.03.019

Economides C, Economides MJ (2010) Sequestering carbon dioxide in a closed underground volume. J Pet Sci Eng 70(1-2):123-130

Egermann P, Bazin B, Vizika O (2005) An experimental investigation of reaction-transport phenomena during $\mathrm{CO}_{2}$ injection. SPE 93674, Proceedings of the 14th middle east oil and gas show, Bahrain, March 2005

Emami-Meybodi H, Hassanzadeh H, Green CP, Ennis-King J (2015) Convective dissolution of $\mathrm{CO}_{2}$ in saline aquifers: progress in modeling and experiments. Int J Greenh Gas Control 40:238266. https://doi.org/10.1016/j.ijggc.2015.04.003

Eng WA-P (2014) Carbon capture and sequestration: real progress taking place

Ennis-King J, Paterson L (2002) Engineering aspects of geological sequestration of carbon dioxide. SPE 77809, Proceedings of the Asia Pacific oil and gas conference and exhibition, Melbourne, Australia, 8-10 October 2002

Foroozesh J, Dier MA, Rezk MG (2018) A simulation study on $\mathrm{CO}_{2}$ sequestration in saline aquifers: trapping mechanisms and risk of $\mathrm{CO}_{2}$ leakage. MATEC Web Conf 225:03004. https://doi. org/10.1051/MATECCONF/201822503004

Friedmann SJ (2007) Geological carbon dioxide sequestration. Elements 3(3):179-184

GCCSI (2017) Alberta carbon trunk line ("ACTL") with north west sturgeon refinery $\mathrm{CO}_{2}$ stream. Glob CCS Inst 2017. https:// www.globalccsinstitute.com/projects/alberta-carbon-trunk -line-actl-north-west-sturgeon-refinery-co2-stream. Accessed 18 May 2017. https://www.google.com/search?q=GCCSI.+Alber ta+Carbon+Trunk+Line+("ACTL")+with+North+West+Sturg eon+Refinery+CO2+Stream.+Glob+CCS+Inst+2017.+https $\% 3 \mathrm{~A} \% 2 \mathrm{~F} \% 2 \mathrm{Fwww}$.globalccsinstitute.com $\% 2$ Fprojects $\% 2 \mathrm{Falb}$ erta-carbon-trunk-line-actl-north-west-sturgeon-refinery-co2stream+(accessed+May+18\%2C+2017).\&oq=GCCSI.+Alber ta+Carbon+Trunk+Line+(“ACTL")+with+North+West+Sturg eon+Refinery+CO2+Stream.+Glob+CCS+Inst+2017.+https $\% 3 \mathrm{~A} \% 2 \mathrm{~F} \% 2 \mathrm{Fwww}$.globalccsinstitute.com $\% 2$ Fprojects $\% 2 \mathrm{Falb}$ erta-carbon-trunk-line-actl-north-west-sturgeon-refinery-co2stream $+($ accessed + May $+18 \% 2 C+2017) . \& a q s=$ chrome..69i57
$.684411 \mathrm{j} 0 \mathrm{j} 7 \&$ sourceid $=$ chrome \&ie $=\mathrm{UTF}-8$. Accessed $16 \mathrm{Nov}$ 19

Guen YL, Huot M, Loizzo M, Poupard O (2011) Well integrity risk assessment of Ketzin injection well (ktzi-201) over a prolonged sequestration period. Energy Procedia 4:4076-4083. https://doi. org/10.1016/j.egypro.2011.02.350

Hao Y, Yang D, Zhou Y (2016) A feasibility study of $\mathrm{CO}_{2}$ geologic sequestration integrating reservoir simulation, rock-physics theory, and seismic modeling. Geophysics 81:M71-M82. https:// doi.org/10.1190/GEO2015-0614.1

Hascakir B (2017) Carbon dioxide storage in high asphaltene content oil reservoirs. Paper SPE-185559 presented at SPE Latin America and Caribbean petroleum engineering conference held in Buenos Aires, 17-19 May 2017

Hebach A, Oberhof A, Dahmen N, Kögel A, Ederer H, Dinjus E (2002) Interfacial tension at elevated pressures-measurements and correlations in the water + carbon dioxide system. J Chem Eng Data 47:1540-1546. https://doi.org/10.1021/je025569p

Hesse MA (2008) Mathematical modeling and multiscale simulation of $\mathrm{CO}_{2}$ storage in saline aquifers. Stanford University

Holloway S, Savage D (1993) The potential for aquifer disposal of carbon dioxide in the UK. Energy Convers Manag 34(9-11):925-932

Hortle A, de Caritat P, Stalvies C, Jenkins C (2011) Groundwater monitoring at the Otway project site, Australia. Energy Procedia 4:5495-5503. https://doi.org/10.1016/j.egypro.2011.02.535

Hosseini SA, Lashgari H, Choi JW, Nicot JP, Lu J, Hovorka SD (2013) Static and dynamic reservoir modeling for geological $\mathrm{CO}_{2}$ sequestration at Cranfield, Mississippi, U.S.A. Int J Greenh Gas Control 18:449-462. https://doi.org/10.1016/j.ijggc.2012.11.009

Hosseininoosheri P, Hosseini SA, Nuñez-López V, Lake LW (2018) Impact of field development strategies on $\mathrm{CO}_{2}$ trapping mechanisms in a $\mathrm{CO}_{2}-$ EOR field: a case study in the permian basin (SACROC unit). Int J Greenh Gas Control 72:92-104. https:// doi.org/10.1016/j.ijggc.2018.03.002

Hovorka SD (2006) Frio brine storage experiment-lessons learned. In: 8th international conference on greenhouse gas control technology, pp 6-13. https://www.google.com/searc $\mathrm{h} ? \mathrm{q}=$ Hovorka + SD.+ Frio + Brine + Storage + Experiment Lessons+Learned.+8th+Int.+Conf.+Greenh.+Gas+Contr ol + Technol. $\% 2 \mathrm{C}+2006 \% 2 \mathrm{C}+$ p. $+6-13 . \&$ oq $=$ Hovor $\mathrm{ka}+\mathrm{SD} .+$ Frio + Brine + Storage + Experiment-Lessons + Learn ed. +8 th + Int. + Conf. + Green h. + Gas + Control+Techn ol. $\% 2 \mathrm{C}+2006 \% 2 \mathrm{C}+$ p. $+6-13 . \&$ aqs $=$ chrome..69i57.1143857j0j $9 \&$ sourceid $=$ chrome \&ie $=$ UTF-8. Accessed 16 Nov 19

Iglauer S, Pentland $\mathrm{CH}$, Busch A (2015) $\mathrm{CO}_{2}$ wettability of seal and reservoir rocks and the implications for carbon geosequestration. Water Resour Res 51:729-774. https://doi. org/10.1002/2014WR015553

Izgec O, Demiral B, Bertin HJ, Akin S (2005) Experimental and numerical investigation of carbon sequestration in saline aquifers. In: SPE/EPA/DOE exploration and production environmental conference, Society of Petroleum Engineers. https://doi. org/10.2118/94697-STU

Jeddizahed J, Rostami B (2016) Experimental investigation of injectivity alteration due to salt precipitation during $\mathrm{CO}_{2}$ sequestration in saline aquifers. Adv Water Resour 96:23-33. https://doi. org/10.1016/j.advwatres.2016.06.014

Jia W, McPherson B, Pan F, Dai Z, Moodie N, Xiao T (2018) Impact of three-phase relative permeability and hysteresis models on forecasts of storage associated With $\mathrm{CO}_{2}$-EOR. Water Resour Res 54:1109-1126

Jin L, Hawthorne S, Sorensen J, Pekot L, Kurz B, Smith S, Heebink L, Herdegen V, Bosshart N, Torres J, Dalkhaa C, Peterson K, Gorecki C, Steadman E, Harju J (2017) Advancing $\mathrm{CO}_{2}$ enhanced oil recovery and storage in unconventional oil 
play-experimental studies on Bakken shales. Appl Energy 208:171-183. https://doi.org/10.1016/j.apenergy.2017.10.054

Kelley M, Abbaszadeh M, Mishra S, Mawalkar S et al (2014) Reservoir characterization from pressure monitoring during $\mathrm{CO}_{2}$ injection into a depleted pinnacle reef-MRCSP commercialscale CCS demonstration project. researchgate.net

Kim TW, Tokunaga TK, Bargar JR, Latimer MJ, Webb SM (2013) Brine film thicknesses on mica surfaces under geologic $\mathrm{CO}_{2}$ sequestration conditions and controlled capillary pressures. Water Resour Res 49:5071-5076. https://doi.org/10.1002/ wrcr.20404

Klara SM, Srivastava RD, McElvried HG (2003) Integrated collaborative technology development program for $\mathrm{CO}_{2}$ sequestration in geologic formations. Energy Convers Manag 44:2699-2712

Kokal SL, Sayegh SG (1995) Asphaltenes: the cholesterol of petroleum. Paper SPE 29787 presented at the 1995 Middle East Oil Show, Bahrain, 11-14 March

Koperna G, Carpenter S, Petrusak R, Procedia RT-E (2014) Project assessment and evaluation of the area of review (AoR) at the Citronelle SECARB Phase III Site, Alabama USA. Elsevier, Amsterdam

Kopp A, Class H, Helmig R (2009) Investigations on $\mathrm{CO}_{2}$ storage capacity in saline aquifers-part 2: estimation of storage capacity coefficients. Int J Greenh Gas Control 3:277-287. https://doi.org/10.1016/j.ijggc.2008.10.001

Korbøl R, Kaddour A (1995) Sleipner vest $\mathrm{CO}_{2}$ disposal-injection of removed $\mathrm{CO}_{2}$ into the Utsira formation. Energy Convers Manag 36(6-9):509-512

Lackner KS (2003) Climate change: a guide to $\mathrm{CO}_{2}$ sequestration. Science 300(5626): 1677-1678

Lashof DA, Ahuja DR (1990) Relative contributions of greenhouse gas emissions to global warming. Nature 344(6266):529-531

Le Guen Y, Gouevec JL, Chammas BG, Poupard O, Van Der Beken A, Jammes L (2008) $\mathrm{CO}_{2}$ storage-managing the risk associated with well leakage over long timescales. Paper SPE 116424 presented at the 2008 Asia Pacific oil \& gas conference and exhibition held in Perth, Australia, 20-22 October

Leung DYC, Caramanna G, Maroto-Valer MM (2014) An overview of current status of carbon dioxide capture and storage technologies. Renew Sustain Energy Rev 39:426-443

Lindeberg E, Zweigel P, Bergmo P, Ghaderi A, Lothe A (2001) Prediction of $\mathrm{CO}_{2}$ distribution pattern improved by geology and reservoir simulation and verified by time lapse seismic. Greenh Gas Control Technol 372:377

Liu Q, Maroto-Valer MM (2011) Parameters affecting mineral trapping of $\mathrm{CO}_{2}$ sequestration in brines. Greenh Gases Sci Technol 1:211-222. https://doi.org/10.1002/ghg.29

Loizzo M (2008) Assessing long-term $\mathrm{CO}_{2}$ containment performance: cement evaluation in Otway CRC-1. Paper SPE 115707 presented at the 2008 SPE Asia Pacific oil \& gas conference and exhibition held in Perth, Australia, 20-22 October

Luc TAB, Ikelle T, Holdich SA (20040 Experimental and simulation studies of sequestration of supercritical carbon dioxide in depleted gas reservoirs. Texas A\&M University

Luo T, Zhou L, Jiao Z, Bai Y, Wang S (2014) The Ordos Basin: a premier basin for integrating geological $\mathrm{CO}_{2}$ storage with enhanced oil recovery projects in China. Energy Procedia 63:7772-7779. https://doi.org/10.1016/j.egypro.2014.11.811

Mackenzie FT, Lerman A, Ver LMB (2001) AAPG studies in geology 47: geological perspectives of global climate change, chapter 3recent past and future of the global carbon cycle

Mahmoodpour S, Rostami B (2017) Design-of-experiment-based proxy models for the estimation of the amount of dissolved $\mathrm{CO}_{2}$ in brine: a tool for screening of candidate aquifers in geosequestration. Int J Greenh Gas Control 56:261-277. https://doi. org/10.1016/j.ijggc.2016.11.031
Malik QM, Islam MR (2000) $\mathrm{CO}_{2}$ injection in the Weyburn field of Canada: optimization of enhanced oil recovery and greenhouse gas storage with horizontal wells. In: SPE/DOE improved oil recovery symposium, Society of Petroleum Engineers

Marini L (2006) Geological sequestration of carbon dioxide: thermodynamics, kinetics, and reaction path modeling. Elsevier, Amsterdam

Mathieson A, Wright I, Roberts D, Ringrose P (2009) Satellite imaging to monitor $\mathrm{CO}_{2}$ movement at Krechba, Algeria. Energy Procedia 1(1):2201-2209

Mathieson A, Midgely J, Wright I, Saoula N, Ringrose P (2011) In Salah $\mathrm{CO}_{2}$ Storage JIP: $\mathrm{CO}_{2}$ sequestration monitoring and verification technologies applied at Krechba, Algeria. Energy Procedia 4:3596-3603

MIT (2015) Carbon capture and sequestration technologies. Massachusetts Inst Technol 2015. https://sequestration.mit.edu/tools /projects/index.html. Accessed 1 Oct 2015. https://www.googl e.com/search?q=MIT.+Carbon+Capture+and+Sequestrat ion+Technologies.+Massachusetts+Inst+Technol+2015.+https $\% 3 \mathrm{~A} \% 2 \mathrm{~F} \% 2 \mathrm{Fsequestration}$.mit.edu $\% 2 \mathrm{Ftools} \% 2 \mathrm{Fprojects} \% 2 \mathrm{Find}$ ex.html+(accessed+October+1\%2C+2015).\&oq=MIT.+Carbo $\mathrm{n}+$ Capture+and+Sequestration+Technologies.+Massachuse tts+Inst+Technol+2015. +https\%3A\%2F\%2Fsequestration.mit. edu $\% 2$ Ftools $\% 2$ Fprojects $\% 2$ Findex.html+(accessed+Octob er $+1 \% 2 \mathrm{C}+2015) . \&$ aqs $=$ chrome..69i57.197692j0j7 \&sourc eid $=$ chrome $\& i e=U T F-8$. Accessed 16 Nov 19

Mkemai RM, Bin G (2019) A modeling and numerical simulation study of enhanced $\mathrm{CO}_{2}$ sequestration into deep saline formation: a strategy towards climate change mitigation. Mitig Adapt Strateg Glob Change. https://doi.org/10.1007/s11027-019-09900 $-6$

Mkemai RM, Gong B (2020) Geological performance evaluation of $\mathrm{CO}_{2}$ sequestration in depleted oil reservoirs: a simulation study on the effect of water saturation and vertical to horizontal permeability ratio. J Nat Gas Sci Eng 76:103196. https://doi. org/10.1016/j.jngse.2020.103196

Mohamed I, Nasr-El-Din HA (2013) Fluid/rock interactions during $\mathrm{CO}_{2}$ sequestration in deep saline carbonate aquifers: laboratory and modeling studies. SPE J 18:468-485. https://doi. org/10.2118/151142-PA

Möller F, Liebscher A, Martens S, Schmidt-Hattenberger C, Streibel $\mathrm{M}$ (2014) Injection of $\mathrm{CO}_{2}$ at ambient temperature conditionspressure and temperature results of the "cold injection" experiment at the Ketzin Pilot Site. Energy Procedia 63:6289-6297. https://doi.org/10.1016/j.egypro.2014.11.660

Moloney JJ et al (2008) Corrosion and hydrate control in wet sour gas transmission systems. Paper SPE 115074, was presented at the 2008 SPE Asia Pacific oil \& gas conference and exhibition held in Perth, Australia, 20-22 October 2008

Momeni A, Aghajani M, Zargar G (2012) A simulation study of carbon dioxide sequestration in a depleted oil reservoir. Pet Sci Technol 30:751-765. https://doi.org/10.1080/10916466.2010.490809

Muggeridge A, Abacioglu Y, England W, Smalley C (2004) Dissipation of anomalous pressures in the subsurface. J Geophys Res Solid Earth. https://doi.org/10.1029/2003JB002922

Negrescu M (2007) Economic modelling of an oil and gas project involving carbon capture and storage-Snohvit LNG Project (Barents Sea, Norway). In: EUROPEC/EAGE conference and exhibition, Society of Petroleum Engineers. https://doi. org/10.2118/107430-MS

Nelson EB et al (1990) Well cementing. TSL-4135/ICN-01557200, Schlumberger Educational Services

Nooner SL, Eiken O, Hermanrud C, Sasagawa GS, Stenvold T, Zumberge MA (2007) Constraints on the in situ density of $\mathrm{CO}_{2}$ within the Utsira formation from time-lapse seafloor gravity measurements. Int J Greenh Gas Control 1(2):198-214

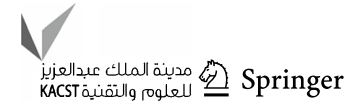


Novosad Z, Costain TG (1990) Experimental and modeling studies of asphaltene equilibria for a reservoir under $\mathrm{CO}_{2}$ injection. Paper SPE 20530, presented at the 65th annual technical conference and exhibition of the SPE held in New Orleans, LA, 23-28 September

Nygaard R, Salehi S, Weideman B, Lavoie RG (2014) Effect of dynamic loading on wellbore leakage for the Wabamun area $\mathrm{CO}_{2}$-sequestration project. Society of Petroleum Engineers. https ://doi.org/10.2118/146640-PA

Okwen RT, Stewart MT, Cunningham JA (2010) Analytical solution for estimating storage efficiency of geologic sequestration of $\mathrm{CO}_{2}$. Int J Greenh Gas Control 4:102-107. https://doi.org/10.1016/j. ijggc.2009.11.002

Oloruntobi OS, LaForce TC (2009) Effect of aquifer heterogeneity on $\mathrm{CO}_{2}$ sequestration. In: EUROPEC/EAGE conference and exhibition, Society of Petroleum Engineers. https://doi. org/10.2118/121776-MS

Pamukcu Y, Hurter S, Jammes L, Vu-Hoang D, Pekot L (2011) Characterizing and predicting short term performance for the In Salah Krechba field CCS joint industry project

Pan L, Oldenburg CM (2020) Mechanistic modeling of $\mathrm{CO}_{2}$ well leakage in a generic abandoned well through a bridge plug cement-casing gap. Int J Greenh Gas Control 97:103025. https ://doi.org/10.1016/j.ijggc.2020.103025

Pham THV, Maast TE, Hellevang H, Aagaard P (2011) Numerical modeling including hysteresis properties for $\mathrm{CO}_{2}$ storage in Tubåen formation, Snøhvit field, Barents Sea. Energy Procedia 4:3746-3753

Prusty BK (2008) Sorption of methane and $\mathrm{CO}_{2}$ for enhanced coalbed methane recovery and carbon dioxide sequestration. J Nat Gas Chem 17:29-38. https://doi.org/10.1016/S1003 -9953(08)60022-5

Puckette J, Al-Shaieb Z, Puckette J, Al-Shaieb Z (2003) Naturally underpressured reservoirs: applying the compartment concept to the safe disposal of liquid waste

Qi R, LaForce TC, Blunt MJ (2009) Design of carbon dioxide storage in aquifers. Int J Greenhouse Gas Control 3(2):195-205

Ramanathan V (1988) The greenhouse theory of climate change: a test by an inadvertent global experiment. Science 240:293-299

Ranasinghe N (2013) Regulating a pilot project in the absence of legislation specific to carbon storage. Energy Procedia 37:62026215. https://doi.org/10.1016/j.egypro.2013.06.549

Riaz A, Cinar Y (2014) Carbon dioxide sequestration in saline formations: part I-review of the modeling of solubility trapping. J Pet Sci Eng 124:367-380. https://doi.org/10.1016/j. petrol.2014.07.024

Ringrose PS, Mathieson AS, Wright IW, Selama F, Hansen O, Bissell R, Saoula N, Midgley J (2013) The In Salah $\mathrm{CO}_{2}$ storage project: lessons learned and knowledge transfer. Energy Procedia 37:6226-6236

Rutqvist J, Vasco DW, Myer L (2009) Coupled reservoir-geomechanical analysis of $\mathrm{CO}_{2}$ injection at In Salah, Algeria. Energy Procedia 1(1):1847-1854

Schacht U, Jenkins C (2014) Soil gas monitoring of the Otway Project demonstration site in SE Victoria, Australia. Int J Greenh Gas Control 24:14-29. https://doi.org/10.1016/j.ijggc .2014.02.007

Schaefer CE, DiCarlo DA, Blunt MJ (2000) Experimental measurement of air-water interfacial area during gravity drainage and secondary imbibition in porous media. Water Resour Res 36(4):885-890

Sengul M (2006) $\mathrm{CO}_{2}$ sequestration-a safe transition technology. In: SPE international health, safety \& environment conference, Society of Petroleum Engineers

Seo JG, Mamora DD (2005) Experimental and simulation studies of sequestration of supercritical carbon dioxide in depleted gas reservoirs. J Energy Resour Technol Trans ASME 127:1-5. https ://doi.org/10.1115/1.1790538

Shafeen A, Croiset E, Douglas PL, Chatzis I (2004) $\mathrm{CO}_{2}$ sequestration in Ontario, Canada. Part I: storage evaluation of potential reservoirs. Energy Convers Manag 45(17):2645-2659

Sharma S, Cook P, Jenkins C, Steeper T, Lees M, Ranasinghe N (2011) The $\mathrm{CO}_{2}$ CRC Otway Project: Leveraging experience and exploiting new opportunities at Australia's first CCS project site. Energy Procedia 4:5447-5454. https://doi.org/10.1016/j.egypr o.2011.02.530

Shukla R, Ranjith P, Haque A, Choi X (2010) A review of studies on $\mathrm{CO}_{2}$ sequestration and caprock integrity. Fuel 89(10):2651-2664

Soltanian MR, Amooie MA, Cole DR, Graham DE, Hosseini SA, Hovorka S, Pfiffner SM, Phelps TJ, Moortgat J (2016) Simulating the Cranfield geological carbon sequestration project with high-resolution static models and an accurate equation of state. Int J Greenh Gas Control 54:282-296. https://doi.org/10.1016/j. ijggc.2016.10.002

Soltanian MR, Amooie MA, Dai Z, Cole D, Moortgat J (2016) Critical dynamics of gravito-convective mixing in geological carbon sequestration. Sci Rep. https://doi.org/10.1038/srep35921

Soltanian MR, Amooie MA, Cole D, Graham D, Pfiffner S, Phelps $\mathrm{T}$, Moortgat J (2018) Transport of perfluorocarbon tracers in the Cranfield Geological Carbon Sequestration Project. Greenh Gases Sci Technol 8:650-671. https://doi.org/10.1002/ghg.1786

Soltanian MR, Amooie MA, Cole DR, Darrah TH, Graham DE, Pfiffner SM, Phelps TJ, Moortgat J (2018) Impacts of methane on carbon dioxide storage in brine formations. Groundwater 56:176-186. https://doi.org/10.1111/gwat.12633

Soltanian MR, Hajirezaie S, Hosseini SA, Dashtian H, Amooie MA, Meyal A, Ershadnia R, Ampomah W, Islam A, Zhang X (2019) Multicomponent reactive transport of carbon dioxide in fluvial heterogeneous aquifers. J Nat Gas Sci Eng 65:212-223. https:// doi.org/10.1016/J.JNGSE.2019.03.011

Stirling M, Litchfield N, Gerstenberger M, Clark D, Bradley B, Beavan J, McVerry G, Van Dissen R, Nicol A, Wallace L, Buxton R (2011) Preliminary probabilistic seismic hazard analysis of the $\mathrm{CO}_{2} \mathrm{CRC}$ Otway Project Site, Victoria, Australia. Bull Seismol Soc Am 101:2726-2736. https://doi.org/10.1785/0120110049

Streibel M, Finley RJ, Martens S, Greenberg S, Möller F, Liebscher A (2014) From pilot to demo scale-comparing Ketzin results with the Illinois Basin-Decatur Project. Energy Procedia 63:63236334. https://doi.org/10.1016/j.egypro.2014.11.665

Sun Q, Ampomah W, Kutsienyo EJ, Appold M, Adu-Gyamfi B, Dai Z, Soltanian MR (2020) Assessment of $\mathrm{CO}_{2}$ trapping mechanisms in partially depleted oil-bearing sands. Fuel 278:118356. https ://doi.org/10.1016/j.fuel.2020.118356

Taheri A, Torsaeter O, Wessel-Berg D, Soroush M (2012) Experimental and simulation studies of density-driven-convection mixing in a hele-shaw geometry with application for $\mathrm{CO}_{2}$ sequestration in brine aquifers. In: SPE Europec/EAGE annual conference, Society of Petroleum Engineers. https://doi.org/10.2118/154908-MS

Torp TA, Gale J (2004) Demonstrating storage of $\mathrm{CO}_{2}$ in geological reservoirs: the Sleipner and SACS projects. Energy 29(9-10):1361-1369

Trevisan L, Illangasekare TH, Meckel TA (2017) Modelling plume behavior through a heterogeneous sand pack using a commercial invasion percolation model. Geomech Geophys Geoenergy Georesour 3:327-337. https://doi.org/10.1007/s40948-017-0055-5

Trivedi JJ, Babadagli T, Lavoie RG, Nimchuk D (2007) Acid gas sequestration during tertiary oil recovery: optimal injection strategies and importance of operational Parameters. J Can Pet Technol. https://doi.org/10.2118/07-03-06

Viete DR, Ranjith PG (2006) The effect of $\mathrm{CO}_{2}$ on the geomechanical and permeability behaviour of brown coal: implications for coal 
seam $\mathrm{CO}_{2}$ sequestration. Int J Coal Geol 66:204-216. https://doi. org/10.1016/j.coal.2005.09.002

Voormeij DA, Simandl GJ (2002) Geological and mineral $\mathrm{CO}_{2}$ sequestration options: a technical review. British Columbia Geological Survey, Geological Fieldwork, vol 265

Wang K, Xu T, Wang F, Tian $\mathrm{H}$ (2016) Experimental study of $\mathrm{CO}_{2}$-brine-rock interaction during $\mathrm{CO}_{2}$ sequestration in deep coal seams. Int J Coal Geol 154-155:265-274. https://doi. org/10.1016/j.coal.2016.01.010

Wellman TP, Grigg RB, McPherson BJ, Svec RK, Lichtner PC (2003) Evaluation of $\mathrm{CO}_{2}$-brine-reservoir rock interaction with laboratory flow tests and reactive transport modeling. In: SPE international symposium on oilfield chemistry, pp 233-241. https://doi. org/10.2523/80228-ms

White JA, Chiaramonte L, Ezzedine S, Foxall W, Hao Y, Ramirez A, McNab W (2014) Geomechanical behavior of the reservoir and caprock system at the In Salah $\mathrm{CO}_{2}$ storage project. Proc Natl Acad Sci 111(24):8747-8752

Worth K, White D, Chalaturnyk R, Sorensen J, Hawkes C, Rostron B, Johnson J, Young A (2014) Aquistore project measurement, monitoring, and verification: from concept to $\mathrm{CO}_{2}$ injection. Energy Procedia 63:3202-3208. https://doi.org/10.1016/j.egypr o.2014.11.345

Yamamoto H (2004) Using time-lapse seismic measurements to improve flow modeling of $\mathrm{CO}_{2}$ injection in the Weyburn field: a naturally fractured, layered reservoir. Doctoral dissertation, Colorado School of Mines

Yamamoto H, Fanchi JR, Davis TL (2004) Integration of time-lapse seismic data into a flow model study of $\mathrm{CO}_{2}$ injection into the Weyburn field. In: SPE annual technical conference and exhibition, Society of Petroleum Engineers

Yang Z, Chen YF, Niemi A (2020) Gas migration and residual trapping in bimodal heterogeneous media during geological storage of $\mathrm{CO}_{2}$. Adv Water Resour 142:103608. https://doi.org/10.1016/j. advwatres.2020.103608
Zanganeh P, Ayatollahi S, Alamdari A, Zolghadr A, Dashti H, Kord S (2012) Asphaltene deposition during $\mathrm{CO}_{2}$ injection and pressure depletion: a visual study. Energy Fuels 26(2):1412-1419

Zhang Z, Agarwal RK (2012) Numerical simulation and optimization of $\mathrm{CO}_{2}$ sequestration in saline aquifers for vertical and horizontal well injection. Comput Geosci 16:891-899. https://doi. org/10.1007/s10596-012-9293-3

Zhang L, Ren S, Ren B, Zhang W, Guo Q, Zhang Li (2011) Assessment of $\mathrm{CO}_{2}$ storage capacity in oil reservoirs associated with large lateral/underlying aquifers: case studies from China. Int J Greenh Gas Control 5:1016-1021. https://doi.org/10.1016/j. ijggc.2011.02.004

Zhang Z, Li Y, Zhang W, Wang J, Soltanian MR, Olabi AG (2018) Effectiveness of amino acid salt solutions in capturing $\mathrm{CO}_{2}$ : a review. Renew Sustain Energy Rev 98:179-188. https://doi. org/10.1016/j.rser.2018.09.019

Zhang K, Jia N, Liu L (2019) $\mathrm{CO}_{2}$ storage in fractured nanopores underground: phase behaviour study. Appl Energy 238:911-928. https://doi.org/10.1016/j.apenergy.2019.01.088

Zhao X, Ma R, Zhang F, Zhong Z, Wang B, Wang Y, Li Y, Weng L (2017) The latest monitoring progress for Shenhua $\mathrm{CO}_{2}$ storage project in China. Int J Greenh Gas Control 60:199-206. https:// doi.org/10.1016/j.ijggc.2017.03.004

Zhou Q, Birkholzer JT, Tsang CF, Rutqvist J (2008) A method for quick assessment of $\mathrm{CO}_{2}$ storage capacity in closed and semiclosed saline formations. Int J Greenh Gas Control 2:626-639. https://doi.org/10.1016/j.ijggc.2008.02.004

Publisher's Note Springer Nature remains neutral with regard to jurisdictional claims in published maps and institutional affiliations. 